The Death Drive in Psychoanalysis: Decoding Three Prominent Theories from

Spielrein, Freud and Klein

by

Danielle Star

A thesis submitted to the Faculty of Graduate and Postdoctoral Affairs in Partial Fulfillment of the requirements for the degree of

Master

in

Philosophy

Carleton University

Ottawa, Ontario

(C)2018

Danielle Star 


\begin{abstract}
The death drive is a concept used by a number of psychoanalytic theorists with very little consensus on what this drive actually is or does. When each psychoanalyst makes use of the term it is unclear whether they are even referring to the same thing. In this thesis, three main theories on the death drive from Sabina Spielrien, Sigmund Freud, and Melanie Klein are examined. This thesis seeks to make sense of what exactly each thinker believes the death drive to be despite the complexity and sometimes lack of clarity in their works. Throughout each chapter, comparisons and differences between each psychoanalyst are drawn in order to find what is held in common between them. By tackling each theory this way, this thesis seeks to formulate some idea of what can be said concretely about the death drive.
\end{abstract}


TABLE OF CONTENTS

INTRODUCTORY REMARKS

CHAPTER 1: SPIELREIN 10

CHAPTER 2: FREUD 42

CHAPTER 3: KLEIN 67

CONCLUDING REMARKS 89

REFERENCES 95 


\section{INTRODUCTORY REMARKS}

The sex drive is universally known and an essential part of psychoanalysis, especially of the Freudian variety. It is, in fact, the backbone behind many Freudian theories. A lesser known force in Freud's works is the death drive, said to work in opposition to the sex drive. The instincts towards life which include the sex drive have become known as "Eros", the opposing forces towards death as "Thanatos". Freud's thoughts on the death drive are developed primarily in his work Beyond the Pleasure Principle. As much as Freud is credited with this drive, he is thought to have been inspired by one of his and Carl Jung's students, a lesser-known psychoanalyst, Sabina Spielrein. Spielrein's work "Destruction as the Cause of Coming to Being" was largely unappreciated by her mentors and editors Jung and Freud during its production. As such, many of her great insights on the death drive and the nature of sexual repression went unrecognized during her time.

There are many ways in which Freud's theories on the death drive as established in Beyond the Pleasure Principle differ from Spielrein's own conception. In fact, Freud himself seems to have a few differing ideas in his own works about the nature of the death drive. There is little consensus throughout psychoanalytic history about what the death drive is exactly and how it manifests itself. The aim of this thesis is to figure out what has been said about the death drive by some of the most important thinkers in the field and propose a reconciliation to the parts of their theories that do not agree. In particular, I will argue for the case that what separates these various thinkers is the difference between "death" and "destruction".

There are three main psychoanalysts I have chosen to write about in this thesis: Sabina Spielrein, Sigmund Freud, and Melanie Klein. Although her work was not very 
well-known during her lifetime, Spielrein is important to include in the discussion on the death drive as she is one of the first people to write extensively on the topic and is considered to be the first to have proposed the idea. Freud is very important to the discussion as well. He further developed the ideas proposed by Spielrein and made them more prominent in psychoanalysis. I have chosen to include Melanie Klein as she was an inheritor of Freud's concept and used it to account for aggression to an extent Freud had not managed to achieve.

\section{Spielrein}

The first psychoanalyst I will be talking about in this work is Sabina Spielrein. Spielrein was a student of both Freud and Jung. She wrote a number of papers throughout her life but went largely unrecognized for her work as a theoretician. Her best-known paper is "Destruction as the Cause of Coming into Being" which is the main work I will focus on in my thesis. This paper is where Spielrein developed her concept of the death drive.

By some, Spielrein is said to have anticipated Freud's death drive. Others, however, believe that she in fact inspired Freud's own conception of the death drive. One to have proposed this idea is Spielrein's first teacher, Carl Jung, who was in communication with Freud about their shared student. Spielrein presented part of her paper "Destruction as the Cause of Coming into Being" at a meeting of the Vienna Psychoanalytic Society, at which Freud was present. Even Freud himself admits to having initially rejected the idea of a death drive, meaning at the very least that he did not consider himself the originator of the concept. ${ }^{1}$ Furthermore, he references Spielrein in a

\footnotetext{
${ }^{1}$ Peter Gay, Freud : A Life for Our Time, (New York: Norton, 1988), 395.
} 
footnote of his own paper "Beyond the Pleasure Principle" where he developed his personal notion of the death drive. In this footnote, however, he says that Spielrein anticipated his own ideas and does not credit her as a source of inspiration. ${ }^{2}$ In this thesis, I consider Freud and Klein to be successors to an idea developed by Spielrein inasmuch as they have added to and refined a concept that chronologically found early roots with Spielrein. For this reason, I start my thesis with Spielrein. Furthermore, Klein comes last because she builds on many of Freud's concepts in relation to the death drive.

"Destruction as the Cause of Coming into Being" is a very difficult paper to read. Many of Spielrein's ideas are unclear and confusing. She seems to make many logical leaps in parts of the paper and uses personal experience as proof of her theory. Freud's papers Beyond the Pleasure Principle and The Ego and the Id are also difficult in that many of his ideas are convoluted. He also, at times, tries to make new ideas mesh with old theories even when they do not cooperate well with each other. Furthermore, much of the biological material he bases his ideas upon is no longer accepted by present-day science. I have chosen to focus mainly on these primary texts rather than secondary literature. In tackling these primary texts through my own interpretation and not through the interpretations of others, I hope to draw some more clarity on what these psychoanalysts were getting at with the term "death drive".

In "Destruction as the Cause of Coming into Being" Spielrein seeks to answer why there are negative feelings associated with sex. She discovers that there is a

\footnotetext{
${ }^{2}$ Sigmund Freud, Beyond the Pleasure Principle (Mineola, New York: Dover Publications, Inc, 2015).
} 
dimension of sex that results in the destruction of our sex cells. When two sex cells merge and a new life is created, she says we can consider those cells to have ceased to exist as they were. She describes this destruction as a type of death and believes that the unconscious knowledge of this destructive process causes negative feelings in association with sex. Spielrein further states that certain psychological events in life parallel this biological phenomenon. These psychological events include falling in love and the creation of art. For Spielrein, the destructive process on the psychological level involves the destruction of the ego. By falling in love, one merges their ego with another, thus destroying their former self. By creating art, one sacrifices their individual internal image to a broader one that appeals to their audience. Spielrein borrows a term from Jung when she talks about this process. She says that we move from operating for the sake of the individual ego to operating based on the collective unconscious. The ego is replaced by a collective unconscious. It is in these processes both psychological and biological that Spielrein places the death drive. The death drive for Spielrein is the drive to destroy a part of the self in order to create something new, be this a baby, a relationship, or a work of art.

\section{Freud}

Freud's ideas on the death drive are developed mainly in Beyond the Pleasure Principle and The Ego and the Id and differ greatly from Spielrein's. While Spielrein focuses largely on the interpersonal aspect of the death drive (that it arises through our interactions with others) Freud sees it as a much more individualistic drive. He sees it largely as a drive that humans have in their capacity as organisms. This manifests itself in 
two main ways in Freud's work. On the one hand, he views the drive to death as a drive towards mental quiescence. Freud believes that humans seek to reduce outer stimulation as much as possible. He refers to this concept by a number of different terms such as the nirvana principle, conservatism, and the inertia principle. This process impels people to either reduce stimulation or, if that is not possible, to maintain stimulation at a constant level. The death drive acts towards either destroying the outer stimuli our withdrawing the self from all outer stimulation. The state of complete mental quiescence towards which we are oriented is what Freud deems a state of Nirvana. In this way, we either seek to destroy the outer world or else become dead to it by making our mind inactive.

Freud also conceives of the death drive as the organism's drive to cease on the physical level. This is motivated by the nirvana principle. Freud talks about it on a biological level. He claims that it is internally programmed in every organism to die of natural causes. In some ways, this is backed by our current science which views the process of death and aging as naturally occurring in our cells (although much is being done in attempts to reverse this process). This internal programming for Freud is related to the inertia principle because it refers to our drive to completely annihilate all stimulation through death. It is also related to another drive that Freud discusses at length in this works. This is the drive towards repetition. Freud believes humans have a drive to repeat previous events in their lives and that these previous events are typically of a traumatic nature. He believes that we repeat these events in order to become masters over them and be traumatized no longer. Freud says that the drive to repeat our own death is an example of this. We seek to become masters over our own death. As such, Freud believes that although we are driven towards death, we are driven towards death on our 
own terms. Thus, we can explain our self-protective/preservative tendencies in spite of the drive to die. While much of Freud's analysis does not seem immediately obvious, it is important to remember that he is talking about humanity qua organism. The drive to die, which seems unlikely and counterintuitive, is not something we entertain at all on a conscious level - it is something that is hardwired into our lifecycle.

\section{Klein}

The final psychoanalyst I will talk about in my thesis is Melanie Klein. In her work Envy and Gratitude, she elaborates on Freud's concept of the death drive. Whereas Spielrein and Freud focus more on the self-destructive manifestation of the death drive, Klein's view considers also the aggressive manifestation through the destruction of our phantasies of objects which are based on objects we encounter in the world. Inasmuch as they are our own phantasies, Klein believes these objects to be a part of ourselves. Therefore, in destroying our objects, we are destroying ourselves. We become selfdestructive through these acts of aggression.

According to Klein, our separation from the mother's womb is our first great trauma. We are removed from our sense of unity with her. We seek to regain this unity through our interaction with her breast. However, the breast cannot fully satisfy this desire to reunite because the mother's breast cannot always be present. The infant creates two phantasies of the breast based on these interactions. Klein calls these phantasies objects, but they should not be understood as objects outside of ourselves. While they are based on real things that we interact with, the phantasy we make is internalized and made a part of us - it does not truly reflect the outer world. The two phantasies the child creates 
in regards to the breast are the good breast and the bad breast. The good breast is the breast that nourishes the child when the child desires it. The bad breast is the breast which neglects the child. The breast is split into these two objects so that the goodness of the good breast can be preserved. Sometimes, however, we destroy the goodness of the good object. This is where Klein locates the death drive. We destroy the good object by seeing how it has done wrong to us and thus it can no longer be ultimately good - there is some bad mixed into it now. Through our capacity to destroy the goodness of the good object, Klein finds an explanation for the human tendency towards aggression. Ultimately though, the object is a part of us insofar as it is a phantasy. Therefore, by destroying the good object we destroy a part of ourselves. It is through this dimension that Klein explains our tendency toward self-destruction.

\section{Objective}

In the final part of this thesis, I seek to come to an understanding about the similarities and differences among these psychoanalysts' use of the term "death drive." In writing this thesis I hope to uncover some common element in each interpretation. By following this process of analysis, we may be able to say something more concrete about the workings of the death drive in the human psyche - we can formulate some sort of consensus that these psychoanalysts were not able to claim in their own works. 


\section{CHAPTER 1: SPIELREIN}

\section{Death Wish}

Spielrein, Freud, and Jung

Sabina Spielrein was brought into the world of psychoanalysis through her stay at the Burgholzli institute in Zurich, where she was treated for hysteria. Carl Jung was one of those in charge of her treatment. Her treatment was successful, and soon Spielrein graduated from patient to student at the hospital, where she worked as an assistant to Jung. At some point during their time together, Jung and Spielrein entered a romantic relationship. It is unclear whether this relationship developed into a sexual one.

Regardless of whether it was a sexual relationship, Jung's position of power certainly made it an inappropriate one. Their relationship soon became troubled, resulting in a split. Spielrein wrote a letter to Freud at this time, looking for support, as she knew he was close to Jung. She eventually established her own relationship with Freud, regarding him as a new mentor. Due to her close relationships (both professional and personal) with Jung and Freud, Spielrein's work shows influences from both schools. ${ }^{3}$

The term "death drive" is often misinterpreted as a "death wish" - a desire or urge to either die or to kill. For Spielrein, this was particularly a problem during the production of her paper. Initially a patient of Jung's, Spielrein was treated for hysteria. In her treatment with Jung, Spielrein revealed that she harbored masochistic fantasies. Her time as patient was known also to Freud. In editing her paper both likely assumed it would be an introspective piece on her own desires for destruction, rather than the innovative work

\footnotetext{
3 John Kerr, A Most Dangerous Method: The Story of Jung, Freud, and Sabina Spielrein
} (London: Sinclair-Stevenson, 1994). 
on repression that it truly was, ${ }^{4}$ and were too caught up in their own works to realize the important ideas that were coming from one of their students. While often tackling themes of masochism, the paper itself does not seek to explain a tendency in humans towards suicide. It is not destruction of human life that concerns Spielrein. Rather, she seeks to explain the tendency towards destruction of the ego. This sort of destruction is not an annihilation. Instead, it ought to be seen as a transformation. It is the end of something as it was, transforming into something different, and giving rise to a new identity. Thus, this creation of a new identity comes from a destruction of the old identity via transformation: destruction (or transformation) as the cause of coming into being.

Spielrein's paper, however, is not merely about masochism or a desire for selfharm or death. Rather, her paper considers that given that these tendencies exist, what does that say on a much deeper level, about the fundamental set-up and design of the psyche? Spielrein suggests a twofold identity of the psyche. A person identifies both as an individual and as part of a collective. This notion of a collective identity can extend from the coupled identity found between two people in romantic relationships, to the family unit, all the way to the collective that is all of humanity. At certain times, people operate in the interest of their own self, while at others they operate in the interest of this collective identity.

Furthermore, Spielrein proposes that sexual repression can occur through the clash between these disparate parts of the mind. The ego is consciously operating as an individual. Unconsciously, however, we are driven toward the collective state. Merging into the collective threatens our individuality and so the tendency towards processes

\footnotetext{
${ }^{4}$ Ibid.
} 
through which merging occurs is repressed. For Spielrein, love and sex are some of the processes where merging occurs. In love the transformation occurs on a psychological level while the transformation is a biological one in sex.

It is important to note that as a student, Spielrein's fundamental understanding of psychoanalysis was largely informed by Freud. Many of the terms she uses are the same as those in Freud's own works and she bases much of her analysis upon the Freudian paradigm. However, as much as she operates within this paradigm she differs greatly in one important manner. Where Freud focuses more on the psychical mechanisms of the individual, Spielrein places greater emphasis on the way these mechanisms are defined by the individual's relations with others. Freud sees humans much more as isolated individuals who have to deal with disturbances from the outside world. Spielrein, on the other hand, sees humans as very much integrated into this outer world, working with and not against it. It is, in fact, our relationships with others that formulate a large part of what we are. One part of us is our individual self, but another part of us is the self that considers itself as part of a larger species.

Fatima Caropreso talks about two main types of psyche we see in Spielrein's work. These are the ego-psyche and the deeper psyche. The ego psyche is what we consider to be the self, the part of us that operates according to our own individual concerns. The deeper psyche is a part of us that operates for the sake of the entire species of humanity. ${ }^{5}$ Spielrein believes that we have tendencies towards differentiation and assimilation with the collective. The part of us that wishes to differentiate ourselves from

\footnotetext{
${ }^{5}$ Fatima Caropreso, "The Death Drive According to Sabina Spielrein." Psicologia. USP 27, no. 3 (2016): 416.
} 
the collective and preserve our own identity is the ego-psyche. The part of us that wishes to assimilate is the species psyche. ${ }^{6}$

\section{Description by the Opposite}

Spielrein was first inspired to pursue the topics of sexual repression and negativity while observing patients with schizophrenia. In her paper "On the Psychological Content of a Case of Schizophrenia," Spielrein says,

Finally, I want to emphasize the enormous importance of 'description by the opposite,' which was discovered by Freud, for the development of delusions. A particularly important instance of this is the description of sexual activity by death symbols. The reason for this phenomenon is, as I see it, within the character of the sexual act itself, or, to put it more clearly, in the two antagonistic components of sexuality. ${ }^{7}$

These antagonistic components for Spielrein are life and death - she observed that we associate symbols of both these kinds with sex. These two antagonistic components have a direct relation to the aforementioned concepts of individuality and collectivity. For Spielrein, individuality is the point at which the ego starts. It is the life force, the selfidentity we wish to preserve. As such, it corresponds with life symbols. Collectivity on the other hand corresponds with death symbols. It represents the death of one's individuality insofar as the ego is one's individual identity. It is a state to which we are naturally inclined but one that we resist all the same in the hopes of preserving our individual identity. It was Spielrein's fascination with this twofold structure of sexual relations that led her to delve deeper into the relation between sex and death in her paper

\footnotetext{
${ }^{6}$ Ibid, 417.

${ }^{7}$ Sabina Spielrein, "On the Psychological Content of a Case of Schizophrenia (Dementia Praecox), 1911.
} 
"Destruction as the Cause of Coming into Being." In this paper, she wishes to discover the reason why such unpleasant and destructive images can be associated with the reproductive act which is normally seen as both pleasurable and creative.

Spielrein supports the claim that these sex/death symbols exist through introspection, her patient records, and various mythologies. These death symbols have long existed in the unconscious - we find them in the oldest pieces of mythology - but their direct association with the sexual act was made more explicit in the patient cases that Spielrein had studied. As much as she believes these associations to be ingrained into the psyche, she does not hold them as the only force at play in sexual relations; otherwise as Kerr says "the sexual act would degenerate into murder and martyrdom." 8 We would completely give in either to our sadistic or to our masochistic impulses.

Jung's Misreading - Distinction as the Cause

In a first hasty look through Spielrein's paper, Jung mistakenly took the title to be "Distinction as the Cause of Coming into Being." 9 While, Spielrein intended it to be about destruction rather than distinction, it is interesting to look at the paper through that lens. I think there is a sense in which distinction plays a very important role in Spielrein's idea of the process of coming into being. However, I think the exact opposite of distinction is what Spielrein pinpoints as the instigator of creation.

At first glance, however, distinction seems like it could be a plausible cause for Spielrein. She speaks about the desire for transformation and movement. We desire to

\footnotetext{
${ }^{8}$ A Dangerous Method, 167.

${ }^{9}$ A Dangerous Method.
} 
create a new ego for ourselves through the act of loving. It is through distinguishing our individual self from our new couple ego that we give rise to a new identity. For example, someone named Romeo becomes romantically involved with somebody named Juliet. People now refer to him by either his individual identity "Romeo" or his coupled identity "Romeo and Juliet." They think of him either as "Romeo" or as part of "Romeo and Juliet". His friends now invite either "Romeo" or "Romeo and Juliet" to their party. Through distinguishing the difference between these entities, we have created the new coupled entity, "Romeo and Juliet".

Spielrein explains the process of differentiation as such: "Every content appearing in consciousness is a product that differentiates from other, psychologically older, contents. The content is adapted to the present and contains a specific colouring that endows it with the character of its relation to the ego." ${ }^{\prime 10}$ We become conscious of psychological content inasmuch as it differentiates from other images. It means something to us if we can distinguish how it relates to our own ego. Although each form of content is a reiteration of older contents that belong to our ancestors and the collective unconscious, content only becomes meaningful to us and arises to our conscious through distinction - determining how it relates to us in our current condition. Spielrein explains creation through destruction by saying that "No change can take place without destruction of the former condition." 11 We cannot create new content without separating it from its previous condition. We must do away with the old - distinguish new from old - in order to create new content.

\footnotetext{
${ }^{10}$ Sabina Spielrein, "Destruction as the Cause of Coming into Being." Journal of Analytical Psychology 39, no. 2 (1994): 173.

${ }^{11}$ Ibid, 174.
} 
However, the real sense of Spielrein's paper is quite the opposite of "distinction as the cause of coming into being". Rather, it would seem that Spielrein champions assimilation as the cause of coming into being. This is demonstrated through how she explains communication. She says, "If we want to make our specific content accessible to others, we must de-differentiate it: we clothe the specifically personal content and stamp it with the symbolic form of the applicable collective type. Here, we use our secondary tendency, to assimilate or dissolve, which opposes differentiation" ${ }^{12}$ As explained above, the way we create new ideas and images is by first dissolving our personal experience in favour of a more general symbol. We create general ideas through the creation of language - words serving as general symbols for our personal experience. By assimilating our personal experience to the generality of language we are able to create images in other people's minds. Assimilation thus gives rise to creation. Therefore, language is a mechanism of creativity but also of transformation. It can generate new ideas in other people's minds but it must transform (and thus destroy) the original image held by the communicator.

Assimilation as the cause of coming into being is expressed very clearly when Spielrein says, "The instinct for preservation of the species, a reproductive drive, expresses itself psychologically in the tendency to dissolve and assimilate." 13 The reproductive drive she is talking about here is the drive to sexual reproduction. Spielrein claims that it occurs also on a mental level. This drive that gives rise to the creation of new beings, runs on an urge towards assimilation. It is the drive to become one with

\footnotetext{
12 Ibid, 174.
}

13 Ibid. 
another being, a drive to sacrifice one's individual ego for the sake of the collective, thus becoming one with the collective.

\section{Repression}

Spielrein's death drive provides many insights into and a possible explanation for the problem of sexual repression. According to Freud, repression arises when a process that is meant to bring pleasure brings about feelings of displeasure instead. This is because while the process will satisfy our desires on one front, other consequences from the process lead to unpleasurable circumstances. These unpleasurable feelings outweigh the pleasurable and thus the desire is repressed so as to avoid those unpleasurable feelings. Freud declares that "[repression]cannot arise until a sharp cleavage has occurred between conscious and unconscious mental activity" and that "the essence of repression lies simply in turning something away, and keeping it at a distance, from the conscious." 14 Spielrein's paper seeks to rediscover why we have turned something away from the conscious. This notion that we have turned away but that still lurks in the back of our unconscious turns out to be the sex drive.

In the beginning of the paper, she asks, "Why does this most powerful drive, the reproductive instinct, harbour negative feelings in addition to the inherently anticipated positive feelings?"15 One of her leading questions in conducting this investigation is the question of what exactly is perceived to be negative in the sexual act. Where can we locate the source of bad feelings and why would a person avoid an act that is normally

\footnotetext{
${ }^{14}$ Freud, Repression, 1914.

15 "Destruction as the Cause of Coming into Being," 155.
} 
considered inherently pleasurable and sought out for that very reason? Spielrein's guiding question then, is essentially a question about the nature of repression. Repression is to be understood as the suppression or dismissal of desires or feelings that are unwanted by the conscious self. The sex drive constitutes these underlying unconscious desires. Yet, there is something negative about them, unwanted, rejected by the conscious self. Spielrein's question does not take this negativity for granted. Her question is as to how these negative associations arise.

Sexual repression is not necessarily something we find at the outset in early childhood. Spielrein notes that it is something that is taught to children later on by adults. "We attempt to keep the drive within bounds and teach each child to consider the fulfillment of sexual wishes as something dirty and forbidden."16 Negative associations are therefore not necessarily something we find naturally. Children often have a curiosity or interest in sexuality that is tainted with a negative association through chastisement by their parents. The question then becomes why is this chastisement not enough to explain repression? For Freud, it was a satisfactory explanation. Spielrein does not seem to think it is enough and it is not entirely clear why.

A theory of how repression occurs was something highly sought after at this time. For this reason, had they been taken seriously while she was writing, Spielrein's insightful views in "Destruction as the Cause of Coming into Being" could very well have put her on the psychoanalytic map. Before Spielrein started writing there were a few prominent theories working together to attempt to explain repression. None of them

16 Ibid. 
was quite satisfactory. One of these theories was deferred action theory, as proposed by Freud.

Freud's deferred action theory, also known as afterwardsness or Nachträglichkeit, in German, remains an important aspect of Freudian psychoanalysis and continues to be reworked to this day. It refers to the idea of memories of past traumatic childhood events being triggered by present situations. These memories are not true memories but instead should be understood as residues from childhood. When they are triggered, this results in a realization of the true traumatic or sexual nature of the past event that had been repressed or forgotten. Thus, the realization of the repressed event comes about through the experience of an event with similar qualities. For Freud, these realizations are able to occur once a person passes through puberty and can realize the sexual nature of a past event. ${ }^{17}$ Freud's account of repression is not perfectly satisfactory because it does not explain why the initial repression of the event occurs in the first place. Furthermore, while it can explain delayed trauma reaction, it does not capture the general negative demeanour towards sex which Spielrein observed in her patients. This is likely because Freud's theory here was not really about the initial repression but how the repressed event reveals itself after the fact. As for the initial repression, when it come to sexual repression, Freud thinks childhood chastisement is enough to explain why or how the phenomenon of sexual repression occurs. Spielrein seems to think there is a reason we repress sex beyond the chastisement.

\footnotetext{
17 Freud, Project for a Scientific Psychology, http:/users.clas.ufl.edu/burt/freud\%20fleiss\%20letters/200711781-013.pdf
} 
Spielrein's approach to solving this problem of why sexual repression occurs was first to rethink what sexuality is. ${ }^{18}$ The problem with understanding the issue is why something we see as an activity for pleasure would be seen as something to avoid. In order to get a better grasp of the issue at hand. Spielrein starts by reconceptualising the paradigm set up by Freud as the desire for sex being a pleasure-seeking drive. Instead, she sees it as the ego seeking to unite with another through shared emotion and the coming together of male and female sex cells and parts. Kerr says,

Freud continued to define it terms of discharge and pleasure; just this definition made it difficult to conceive why it should be so regularly repressed. Spielrein, by contrast, realized that sexuality could be characterized in quite different terms - as seeking fusion rather than pleasure - and that once it was so conceptualized the problem of sexual repression virtually solved itself. ${ }^{19}$

As Kerr says, once this leap was made in redefining the aims of sexuality, the rest of Spielrein's paper almost logically ensues. This is because the problem of sexual repression cannot be explained through pleasure alone. If pleasure were to be the defining feature, then there would be no negativity in the sexual act itself. By redefining sex as an act of fusion rather than a discharge of pleasure, it becomes more neutral on the grounds of pleasure/unpleasure. There is some physical pleasure in sex as an act of fusion. It is pleasurable in as much as genitals fusing together create a pleasant physical sensation. It is also pleasurable on an emotional level when the act is accompanied by feelings of love or of satiated desires. However, there is also a negative side to fusion as we see in Spielrein's essay. The union that occurs in sex comes at a cost. This cost on the physical level (when it comes to reproductive sex) is the loss of the sex cell. It transforms into

\footnotetext{
18 A Dangerous Method, 319.

19 Ibid.
} 
something new when merging with the cell of the opposite sex. Thus, it is lost as it was. Emotionally, there is a loss of individuality in self. The ego is transformed into a new coupled identity. Losing one's identity on the cellular and mental level in the act of fusion is what is unpleasurable or negative about sex. However, this is only unpleasurable to the ego-psyche. This transformation is highly sought after by the species-psyche because merging with another serves the purposes of the collective.

It is questionable whether all of humanity would hold it to be true that they lose a part of themselves, that their ego dies, in relationships with other people. This interpretation could have been highly coloured by Spielrein's own personal romantic experience. She had just emerged from a particularly bad romantic relationship with Jung at the time of writing this paper. She was greatly taken advantage of by him and likely may have felt that she was compromising her own self and identity for his sake. It is possible then that she is generalizing her own experiences with love to all humanity.

\section{Biological Factor}

At the basis of all of this, Spielrein seeks to explain the nature of repression of the sex drive through a basic biological fact. This basic fact is that sex acts are geared toward the reproductive process. During this process Spielrein says, " a union of female and male cells occurs. The unity of each cell thus is destroyed and, from the product of this destruction, new life originates." ${ }^{20}$ In the sex cells fusing together in this process, each respective cell (the female ovum and the male sperm) ceases to be as they were. They take on a new shape and identity in this process and are therefore, in a sense, destroyed.

20 "Destruction as the Cause of Coming into Being," 156. 
This act is not necessarily a complete destruction, a total death. The material that composes these cells does not disappear; it is reshaped. Therefore, the results of reproduction are better viewed as a sort of transformation or movement. Although we might consider the title of Spielrein's paper as thus misleading, Spielrein still conceives of this transformation as a sort of destruction. She says of this transformation: "An alteration comes over the whole organism; destruction and reconstruction, which under usual circumstances always accompany each other, occur rapidly." ${ }^{21}$ We can say, however, that this destruction is not a true death as may be suggested by the term "death drive". Rather, we can see it as the cell ceasing to be as it was, not ceasing to be altogether.

It is from this impending sense of destruction undergone by the sex cells in reproduction that Spielrein finds the negative feelings associated with sex. Even though we associate it with pleasure and sometimes the joyful act of creating a new family member, we have this underlying knowledge of the destruction that comes with it. She claims, "The joyful feeling of coming into being that is present within the reproductive drive is accompanied by a feeling of resistance, of anxiety or disgust." ${ }^{22}$ It is unclear what Spielrein means by disgust here. By disgust, I would assume Spielrein to mean a sense of repulsion or fear of the harmful or dangerous aspects of sex. This disgust can be a hygienic one - that the organs we use for sex are in the same part of the body that we use to excrete waste. It may also be a fear of transmission of disease. However, Spielrein specifically states that this is not the sort of disgust of which she speaks. It might be the

${ }^{21}$ Ibid, 157.

22 Ibid. 
case again that the disgust Spielrein speaks of is particular to her own feelings about sex. The anxiety Spielrein discusses though is provoked by the fear of destruction. As much as we rejoice in the production of new offspring, there remains the fear of what we lose in ourselves. We mate for the purpose of continuing the species. However, by recognizing the need to procreate, we recognize our own mortality. This physically manifests itself in the destruction of the sex cell. Every act of creation comes at some sort of price.

Spielrein notes that we can observe this phenomenon more prominently in other species. She gives the example of the may fly, claiming that the may fly dies following reproduction. The act of reproduction is then, for them, an actual death sentence. However, she states that this is not entirely the case for humans and more complex species as they are more highly evolved. ${ }^{23}$ It would seem though, that we are to take these less evolved species to be an example of where humanity emerged from. We emerged from species that died off in more immed iate ways after the act of reproduction. We are to see ourselves as emulating this old way of being through the death of our sex cells when the merge together. That being said, we emulate this ancient pattern is in a highly attenuated form, without an actual biological death.

In a similar fashion, we set up the way for our own destruction, our fading away into uselessness, through giving rise to a new generation. As we grow older and weaker, our children take over our place as leaders in the world. They become the ones who dictate how society is run, leaving little space for the opinions of older generations. We give rise to the generation that makes us obsolete when we engage in reproduction. Spielrein quotes Jung at the beginning of her paper: "Our descendants become our most

23 Ibid, 156. 
dangerous enemies for whom we are unprepared." ${ }^{24} \mathrm{We}$ create the generation that renders us obsolete, that threatens our purpose of existence. However, it is also the case that this new generation gives rise to our potential permanence on Earth through the continuation of our genetic material.

On the one hand, it can be said that our descendants threaten us on a physical level. As we get older and our cells age, we become weaker physically. As infants, our descendants are weak and depend upon our care and nourishment. In time, however, as they grow, they become stronger. As our strength starts decreasing, our children start gaining power. They pose a physical threat because they can overpower us.

This physical advantage becomes paralleled by an ideological one. The new generation has greater energy and will to explore new ideas - new morals and rules that society ought to follow. These rules are deemed superior to those of the previous generations because in addition to increased power, the new generation has increased knowledge. Scientific progress and discoveries allow the new generation to learn much more than the previous. These new ideas gain momentum and push out the old paradigm as the new generation takes on the roles previously filled by their elders. Thus, through reproduction the older generation creates a genetic copy which we might call "new and improved". They come from the same genetic material but are more powerful and more intelligent. They are therefore more of an asset to society than the elder and render the elder obsolete.

Spielrein's interpretation of this most basic fact of reproduction tells us not only about the death drive, but also the sex drive. She claims that, "The individual must

24 Jung, "Wandlungen und Symbole der Libido," in "Destruction," 155. 
strongly hunger for this new creation in order to place its own destruction in creation's service." ${ }^{25}$ Our desires for survival of the species must outweigh the fear of destruction and the desire for personal survival.

From here, Spielrein's main thesis revolves around the possibility that biological processes may be mirrored by psychological ones. As much as we undergo a sort of physical transformation when we unite with another in sex, so too do we undergo a psychological one by uniting with another ego in love. Spielrein does not give a detailed description of how she believes this psychological union exhibits itself. I believe her to be discussing how couples who are in love tend to share emotions and share interests with their partner. The greatest example of shared emotion in such a loving relationship is the experience of empathy. Our sympathy for the beloved becomes so strong that it takes on the level of emotional empathy. People feel so much for their partner that it is as if they were their partner. This is also accompanied by the desire to sacrifice oneself for their partner - the desire to preserve the partner as if the partner were oneself. This can come in a dramatic form - the idea of dying for one's beloved - or in simpler forms. It can be sacrificing one's own personal desires to make the partner happy. This could be something as simple as going ice-skating with the partner when one does not like iceskating because it will make their partner happy. A part of one's identity (the part that does not like ice-skating) is sacrificed - part of the ego is destroyed. This is because as part of a couple now, one derives satisfaction from the partner's happiness and wishes to preserve this happiness as if it were their own. The idea of psychological union is thus to feel emotionally in sync (which we might call a sort of cognitive empathy -

25 "Destruction as the Cause of Coming into Being," 156. 
understanding completely the emotions of the partner) with another, as if the two lovers were one person.

\section{Fundamental Aspects of the Unconscious}

Seemingly, Spielrein's paper was written with the intent of discovering a drive that can explain feelings of negativity associated with sex. Thus, it would seem that her paper is simply about the death drive - supporting its existence and explaining how it operates. I believe her paper to be much more ambitious than that, however. Rather than simply a paper about the death drive, I read Spielrein's "Destruction as the Cause of Coming into Being" as a whole to be more of an attempt to map out the structure of the unconscious. In light of the fact that she believes there is more at play than merely a sex drive which desires pleasure (namely, the death drive), Spielrein considers how we might come to understand the inner workings of the unconscious. Thinking in these terms that Spielrein lays out for us leads to a new understanding of the shape of the unconscious. Many of these innovations are informed by Freud's teachings. However, Spielrein uses these insights to create a particular picture of the way in which the psyche operates. In particular I wish to detail what her notion of the death drive says about a desire for familiarity, the idea of a collective human identity, and the notion of subject and object orientation.

\section{Familiarity}

Spielrein bases her concept of our desire for familiarity on some of Freud's teachings. These basically come down to the fact that in our actions and desires we are seeking to repeat the past. Spielrein says, "The statement that we psychically experience very little 
in the present strikes us as paradoxical and yet is correct. An event is feeling-toned for us only to the extent that it can stimulate previously experienced feeling-toned contents that now lie hidden in the unconscious." 26 What she means to say is that the present for us is just a reiteration of past experiences and desires. We feel positively or negatively about the events we experience in the present based on how we perceived similar events in the past. These negative or positive associations are formed for us in childhood, according to Freud. Spielrein says, "Freud traces our subsequent direct or sublimated impulses for love back to the infantile period when we felt our initial pleasurable sensations through our caretakers. We always seek to re-experience these pleasurable sensations." ${ }^{27}$ A concept in psychoanalysis closely related to this idea is regression. Regression means the adult ego's tendency to degenerate back to its earlier childhood form. Due to the fact that our adult impulses stem from our childhood experiences, it is possible for the adult ego to regress back to this earlier form. With her concept of the death drive, however, Spielrein extends this notion of familiarity far into the past beyond just one's childhood phase. The death drive is an ancient drive we inherit from our oldest ancestors. We repeat this familiar pattern over and over again of dying (through loss of individuality) in order to produce new offspring.

However, Spielrein believes that it is not possible that feelings of pleasure can be the only thing which we desire. While she agrees that the desire to increase pleasure and diminish displeasure is an important motivating force in human action, she believes that there must be more than just that if the death drive is to be a motivating force as well. She

\footnotetext{
26 Ibid, 157.

27 Ibid, 158-59.
} 
says, "A wish for self-injury, a joy in pain, is, however, thoroughly incomprehensible if we believe merely in the existence of an ego that only desires pleasure." 28 This joy in pain might otherwise be called masochism. A real pleasure in pain is an uncommon albeit extant phenomenon that is found more prevalently in works of fiction. The wish for selfinjury, however, is almost universally-felt. It occurs in simple cases of self-sabotage. Self-sabotage does not increase pleasure, yet we are compelled to it just the same. Therefore, if we are to believe that such a phenomenon can exist, we cannot say that we are merely compelled by the desire to attain pleasure and to diminish displeasure. There most be more to the ego than this. There must be a part of us that desires more than just avoidance of displeasure. Spielrein believes that the species-psyche is what is more to us. It can seek things that cause pain to the ego-psyche because certain things that harm the ego-psyche benefit its own purposes. By the sex cells dying and a person's ego dying in love, harm is done to the ego-psyche, but the species-pscyche is benefitted by a new life. The continuance of the species is ensured through the sacrifice of the ego.

\section{Collective/Personal identity}

To solve this problem, Spielrein proposes that perhaps Freud is correct in positing an ego that desires pleasure and seeks to avoid displeasure. However, she says that we are more than just our ego. In fact, she proposes that we are more than just our individual self. She says, "I have come to the conclusion that the chief characteristic of an individual is that he is 'dividual'. The closer we approach our conscious thoughts, the more differentiated our images; the deeper we penetrate the unconscious, the more universal and typical the

28 Ibid, 160. 
images. The depth of our psyche knows no 'I', but only it summation, the 'We'." 29 By "dividual" Spielrein means the opposite of individual. Individual means they cannot be divided down further. Spielrein believes that this is because they have already been broken down from a greater source. This bigger source is what Spielrein calls the We or what we might like to call our collective identity. The We is the species-psyche and it is composed of each individual I. Both the I and the We play their own roles in our psyche. We operate differently when we tap into the We mentality than when we are operating for the I. The We is the sake for which we sacrifice ourselves in reproduction. We are no longer merely concerned with our own survival, we are concerned with the survival of the whole of humanity. "Therefore, we see that the collective desires living within us do not correspond to personal desires. The collective psyche wants to assimilate the more recently developed personal psyche while the ego - indeed every part of the ego - strives for self-preservation in its present form."30 The collective psyche is at play in these instances, the personal psyche is quieted. A person's identity becomes lost. As their identity is effectively killed, so too might they die on the personal physical level for the sake of the collective. Using the term assimilation may be an overstatement, but expresses an important point. We can never perfectly assimilate or merge the individual to the collective such that it always acts in the interest of the collective. However, it is simply the case that the survival of the collective psyche depends upon individuals acting in the interest of the collective every now and then.

${ }^{29}$ Ibid, 160.

30 Ibid, 162. 
Spielrein defends the existence of collective-oriented urges through reference to the process by which people communicate with each other. She believes that communication is achieved with a cost, a certain loss of ego. Communication moves from the individual to the collective, thus transforming the particular into something more generally understood. Spielrein talks about the idea of somebody sharing with others a spring day they have experienced. In communicating the particulars of the day to others, something is lost of what the person personally experienced, how each specific detail felt to and was experienced by them. Spielrein describes this process. She says,

To reproduce the experience, we must consciously differentiate the shapes of the trees, grass, and sky, conforming to the current content of consciousness. We no longer are concerned merely with a spring day, but with our own special, personally coloured spring day. On the other hand, when this differentiated product enters another individual's psyche, a retransformation occurs. ${ }^{31}$

We first experience the spring day as a whole, not thinking of our own selves and our individuality but just making ourselves passive to the experience. We do not think of the individual aspects of the day, it is just a nice spring day. We are merged with it. Once we try to convey this experience to others, however, we must break down each aspect. We must separate each element and how it related to us in the moment. After breaking it apart and conveying each piece, we still cannot produce an identical image in the listener. The image created is coloured by the listener's own personal experiences. The experience turns into a new image. Spielrein says,

In each declaration of a thought, which is a portrait of an image; we establish a generalization in which words are symbols, serving to mould universally human and universally comprehensible ideas around the personal. [...] Thus we experience relief in declarations in which we shape a collective image at the expense of our ego-image. ${ }^{32}$

\footnotetext{
31 Ibid, 163.

${ }^{32}$ Ibid, 164.
} 
Although our experience becomes destroyed as it was, we still wish to convey it to others. This is because through this process of destruction, a new experience is created. The destruction of our experience gives rise to a new one. Our personal image turns into a general one. Spielrein says that this is the same thing that happens when we create a piece of art. A piece of art that takes on a special particular meaning to the creator does not always invoke the same feelings in the audience who receives it, yet it still produces a sense of relief in the creator. We feel a great pressure to communicate because of our collective-oriented drive. When that pressure is eliminated, we feel a sense of relief. The process by which we turn our sexual inclination to merge with another towards this inclination to share images with the collective in a destructive way is identified by Spielrein as an example of sublimation. ${ }^{33}$

Sublimation is a concept in psychoanalysis, first introduced by Nietzsche then developed and refined by Freud. Freud defines the process of sublimation as a method of dealing with being unable to satisfy our desires. We make use of this process in order to alleviate the suffering we feel at not being able to satisfy the desire for something that we cannot obtain. In order to alleviate this pain, we focus our desire upon a new obtainable object. Freud says, "The task here is that of shifting the instinctual aims in such a way that they cannot come up against frustration from the external world." 34 What sublimation entails, then, is taking our desires that require release in the external world and directing them towards pleasurable things we can attain for ourselves. Sometimes we transform these into internal pursuits. These are such mental pleasures as creating art or engaging in

\footnotetext{
33 Ibid.

${ }^{34}$ Freud, Civilization and its Discontents, 1930.
} 
other sorts of intellectual work, like writing or research. When we talk about sublimation, we cannot ignore the meaning of the word "sublime". When we think of sublime, we think of something of a higher, loftier quality. With sublimation, we transfer desires of a lower category, typically of a sexual nature (considered to be lower because we share that with less evolved animals), and move them towards what we may deem a higher pursuit. What is important for Freud, however, is not the movement from something lower to higher. Rather, it is the mere transfer of desire. We move our desires to objects that we can attain, making the old desired object obsolete.

The way in which Spielrein draws parallels between the biological and the psychological is an example of such a transference. When we cannot relieve our death drive in the biological way of sexual reproduction, we turn to other methods. We seek to transform our ego rather than our sex cells. We transform our ego by sharing it with the collective through communication or else by creating pieces of art. Our individual expression is lost or destroyed so that it may be interpreted to the public. Yet, it is through this destructive act that we create art or utterances. It is another case of destruction as the cause of coming into being.

\section{Love}

Another way in which we sublimate our worldly experience is through love. So far, we have explained the desire for sex insofar as it is a physical pleasure We do not always just seek sex for the sake of physical pleasure, however. We consider it also to be an emotional pleasure insofar as it is a manifestation of love. Our instinct towards sex often acts in tandem with this instinct towards love - we develop feelings of love for those to 
whom we are sexually attracted. This instinct, however, poses a problem for the ego. With love, the subject desires to unite themselves with another, but the ego essentially wants to preserve itself, to remain divided from the collective and not enter into a unity. Though the ego fights, it is drawn unconsciously to assimilation. This can be in love, where it surrenders itself to the lover, but it can also occur in art where it relinquishes its individuality to produce universal images shared in common with the spectator. Spielrein says, "Where love reigns, the ego, the ominous despot, dies. When one is in love the blending of the ego in the beloved is the strongest affirmation of self, a new ego existence in the person of the beloved." ${ }^{35}$ On the reproductive level, we can say it is a literal death we are condemning our sex cells to destruction. Furthermore, we are preparing for our own destruction as organisms by passing on our genes for posterity. This love and desire to be with someone is a metaphorical death insofar as it is the un-dividuation of the ego. It is the ego combining itself with another to create something bigger than itself, in the same way that the sex cells lose their individuality in joining together. "(Transformation) proceeds with joyous feelings because blending or merging takes place in the beloved (in love). ${ }^{36 "}$ We transform into the one that we love most through this process. Therefore, we become what we love. Spielrein brings up the literary example of Romeo and Juliet when she speaks of this desire for destruction through love. She says that they continue to go through obstacles and hardships throughout the play to expel this destructive impulse towards each other, "yet no impediment is great enough to satisfy their passion, which

\footnotetext{
35"Destruction as the Cause of Coming into Being," 174.
} 36 Ibid, 164. 
finds peace only with complete annihilation, the death of the personality." 37 The only thing that can bring the play and their urges to finality is literal death.

Spielrein explains that the psyche finds peace when it acquires the loved object. She says, "If the desired union with the love object approaches and word becomes deed, the corresponding cluster of images fades, producing a pleasurable feeling of released tension." ${ }^{38}$ The build up of tension coming to its climax, two lovers finally coming together, is the ultimate pleasure because it makes the tension disappear - the lovers can finally find peace. So many stories follow this same set-up. Two people want to be with each other but circumstance keeps them apart. The tension of their separation builds throughout the unfolding of the story until finally they come together in the end, producing vicarious pleasure in the audience. However, this trope takes on a different flavour in a tragedy: "When one is in love, the blending of the ego in the beloved is the strongest affirmation of self, a new ego existence in the person of the beloved. If love fails, the image becomes one of destruction, death." ${ }^{39}$ Anna Karenina grows paranoid and believes she has lost the affection of her beloved Vronsky. She throws herself in front of a train. Aeneas sets off to found Rome, leaving lovelorn Dido behind in Carthage. She throws herself onto a pyre. As Spielrein's paper discusses, merging with another gives rise to a new creation. Merging, however, requires one to lose part of oneself -one dies in a sense. Thus, even if love succeeds, this image Spielrein discusses still turns to death. However, this death also results in a new creation so the image is of destruction or death as the cause of creation/life. If one has given oneself to one's lover, one has submitted

\footnotetext{
${ }^{37}$ Ibid, 173.

${ }^{38}$ Ibid, 164.

39 Ibid, 174.
} 
oneself to this death. If one is rejected by said lover, then the creation through merging cannot come to fruition. All that remains is destruction without creation.

Spielrein briefly considers the possibility that "We could just as easily derive everything from the nurturing instinct rather than sexuality."40 Love could be an attachment formed with the people who provide us with the necessities of personal survival. She speaks of a concurrent unnamed French author who devises his own theory of pleasure from this principle. She sums up his findings by saying that "Essentially, he proposes that the mother loves the child because sucking relieves the mammary glands; one loves a man or a woman because coitus releases the organism's bothersome excretion innocuously. Pleasurable sensation thus is transferred to the object that brings relief." 41 We love the person who provides us the necessities of survival because of the pleasure that comes about through attaining those necessities. Sex relieves the pain of sexual tension, the object who provides that relief is loved for taking on the task. This idea is problematic when it comes to female sexuality. While sex has for a long time been tied to male pleasure, the fact is that women derive physical pleasure from sex as well. However, there are no bothersome secretions discharged by women in sex. Woman instead is described by the bothersome secretions of motherhood that are relieved through breastfeeding. Her pleasure in sex is seen as inconsequential. It is inconsequential because the woman's orgasm is non-functional - it does not give rise to new life. As such, this is not a perfectly satisfactory explanation for a woman's release of sexual tension as it only describes one side of the pleasure derived from human sexuality.

40 Ibid, 159.

${ }^{41}$ Ibid. 


\section{Object/subject}

Through the way that Spielrein conceptualizes love, she deals with another important topic in psychoanalysis, that of subject/object orientation. She says, "In every love, one must distinguish between two conceptual orientations: the first- how one loves; the second- how one is loved. In the first, one is the subject and loves the externally projected object; in the second, one becomes the beloved and loves the self as the object." 42 She proposes that woman is often in the position of object and man in the position of subject. Woman thinks about how she can please the man inasmuch as she is the one sought after, the desirable thing. ${ }^{43}$ She ties these positions to masochism and sadism respectively. When one is in the object position, they consider themselves the object of destruction, they tend towards death. On the other hand, when one is the subject they are the one executing the destruction, they seek to destroy. This perhaps colours Spielrein's own analysis of the death drive. As a woman and due to her past as a patient with masochistic tendencies, Spielrein places herself on the object side of the death drive. We do not hear much about the hostile side of the death drive in Spielrein's paper; the urge to destroy others. Rather, her paper deals much more with the masochistic side; the urge towards self-destruction.

\section{Proof in mythology}

42 Ibid, $168-169$.

43 Ibid, 169. 
In her paper, Spielrein talks about the negative side of sex being ingrained in a collective unconscious. It is not something an individual comes to realize on their own. Rather, it is something we all hold in common at the back of our psyche. It lurks universally in the unconscious due to the basic biological nature of the sex act, a drive passed on hereditarily throughout the generations, though exactly how the biological process transforms itself into a mental one is never clearly explained. Although Spielrein based her discovery on observing her schizophrenic patients, it is as much present in all people throughout different cultures and time periods. As was the fashion in psychoanalysis at the time, Spielrein points to story-telling and mythology to show the existence of this fundamental knowledge across cultures and ages. Though this section of the paper is very long and goes into great detail deconstructing different myths and relating their components back to the death drive, it does not add much to Spielrein's main thesis other than that she believed she could prove the existence of the death drive across many peoples and cultures. I will talk about one of the examples Spielrein provides and the ties she makes to the death drive.

The ancient rite of animal sacrifice is part of mythology that Spielrein calls upon at the end of the paper. She claims that, "In order to avoid god's punishment, a sacrifice is brought to him; he is given another creature whose destruction enables one to come into being." 44 We are given life through the destruction (a literal death in this case) of another being.

When it comes to the topic of sacrifice in religion, Freud focuses in particular on the rite of circumcision. For him, circumcision is meant to serve as a symbol of

${ }^{44}$ Ibid, 179. 
castration. We can analyze this by considering Freud's views on repetition. Freud says that people commit repetitive traumatic acts as a way of overcoming that trauma inflicted on them. In the case of circumcision, the past trauma that has taken place is the death incurred by reproduction. A person comes into being through the death of their previous form (the sex cells). The act of circumcision is thus a symbol of a desire to self-castrate to stop this event from occurring in the future. We seek to become masters over the death that brought us into being by removing the source of destruction. Spielrein says of circumcision, "These are sacrificial ceremonies, self-castrations that symbolically kill one's sexuality without, in reality, destroying the subject. Without destruction, coming into being is impossible." $" 45$ The ego seeks to kill its sexuality to stop its death from occurring in the future. The collective, however, could not allow this to happen because it seeks self-propagation through reproduction. Thus, people have dealt with the trauma through a symbolic castration through the rite of circumcision.

Spielrein calls upon another psychoanalyst, Tausk, to further support the connection between the death drive and castration. Tausk gives an account of a patient who "directly interpreted coitus as castration." The patient expressed a fear that during sex the penis could be amputated by the vagina. ${ }^{46}$ Spielrein interprets this as meaning that the patient draws direct ties between the act of sex and the death of one's sexual identity. Sex results in the death of the sex cells, a partial physical death, which Tausk's patient symbolizes through castration.

\footnotetext{
45 Ibid, 182.

${ }^{46}$ Ibid, 182.
} 
This case does not prove much about the death drive when we consider it as an isolated example. It has a greater impact, however, when we take it as a worry that permeates throughout various societies. A way this worry has transmitted itself crossculturally is through a common symbol known as "vagina dentata". This symbol refers to the idea of a toothed vagina. The toothed vagina is feared by the male as it is capable of biting off his penis. It is often employed in mythology to warn of the dangers of sexual intercourse, and to discourage people from engaging in certain sexual taboos such as promiscuity and rape. Vagina dentata was discovered to be a commonly held fear among neurotic males by Otto Rank. ${ }^{47}$ As per Spielrein's initial intent in making use of mythology, this shows how a fundamental fear of loss of genitalia exhibits itself among many people. It is not a fear restricted to neurotics and is a worry common to many cultures. For Spielrein, this fear of loss of genitalia relates directly back to the loss of sex cells which occurs in sexual reproduction. The appropriate fear (of loss of sex cell) is misplaced and transferred to a fear of the loss of sex organ.

Spielrein's invocation of mythology is problematic on a few levels. The main purpose in invoking mythology is to prove the universality of a certain sentiment expressed by a myth - to show that the symbolism in the myth spans culture and time. This would show that it is something common to all humanity. It would seem, however, that Spielrein fails to demonstrate this. While circumcision is common to many cultures, it is by no means universal. It is possible that Spielrein was once again biased by her personal circumstances, namely her Jewish background. The example of vagina dentata

47 Oxford Dictionary of Psychology, s.v. "vagina dentata", accessed Jan 29, 2018. http:/www.oxfordreference.com.proxy. library.carleton.ca/view/10.1093/acref/97801995 34067.001.0001/acref-9780199534067-e-8716 
in mythology (though not directly mentioned by Spielrein) is equally particular to certain cultures. She speaks of the symbol coming up in a patient of fellow psychoanalyst Victor Tausk. However, she puts too much weight in this one case. Indeed, drawing up more cases would not be enough to attribute this same fear to all of humanity, merely a small subsection.

\section{From Here}

Spielrein ends her paper with this discussion of mythology. She draws no further conclusions about the questions raised in her paper. It is, perhaps, fitting that her paper ends in this way, as many of her leading questions are left unanswered. I will attempt now to see whether her guiding question is answered.

Spielrein starts out with the question of why there are negative feelings associated with the sex drive. She decides that these negative feelings have to do with something that is being repressed about the sex drive. She believes that this repression can be explained through the death drive. Spielrein says that the death drive is the desire to transform the ego - to go from individual to collective. The reason that this is negative is because we believe the individual ego to be who we are - it is our identity. To lose individuality is to lose our identity. We fear this as we fear death. However, we also desire the processes that happen to lead to this destruction such as love and sex insofar as they are pleasurable. Therefore, we become sexually repressed due to the fear of destruction.

There are two main problems here. To start, Freud already has a theory of repression that is not acknowledged in this paper. If Spielrein is trying to replace this theory, she 
does not do a good job. She barely acknowledges the theory and does not explain why or how it fails. A second problem is whether fear of losing identity is really something common to all humanity. Is it possible this is just some issue that Spielrein has due to bad previous relationships? Spielrein does not adequately prove the existence of this fear. The extent of this is present in her appeal to mythology, which is done poorly. It seems, rather, that Spielrein simply asserts its existence as real.

There is still a lot of good to her text. For one, Spielrein has a good insight. There seems to be something in humanity like a drive towards death or destruction and Spielrein was one of the first to pick up on this in psychoanalysis. Whether this exhibits itself in the way she suggests is in discussion. Speilrein also has something interesting to say about our collective and personal identity. If Spielrein's views could be substantiated to the extent that she wishes, that this relationship between creation and destruction bears on multiple facets of life beyond the ones she targets specifically (love and sex), some great metaphysical claims could be made, such as a cosmic coming into being from destruction. 


\section{CHAPTER 2: FREUD}

As discussed in the introduction of this thesis, Freud was late in accepting the idea of something like a death drive. Spielrein completed her paper in 1911 and it took Freud until after the First World War to accept that a concept was needed to explain the aggressive side of humanity.

Peter Gay says,

The great slaughter of $1914-1918$, with stark truths about human savagery revealed in combat and in bellicose editorials, had also forced Freud to assign enhanced stature to aggression. Lecturing at the University of Vienna in the winter semester of 1915, he had asked his auditors to think of the brutality, cruelty, and mendacity now spreading across the civilized world and to admit that evil cannot be excluded from basic human nature. ${ }^{48}$

Thus, Freud felt impelled to take up the idea of the death drive in spite of not mentioning it sooner. He came to a realization that there was something lacking in his theories with regards to humanity's destructive tendencies and took up the death drive to explain this. In this chapter I will examine Freud's theories on the death drive. In particular, I wish to look at what I take to be the two main ways he talks about it. The first way in which the death drive appears in Freud's works is through his idea of our desire to reduce stimulation. We want to be in a mental state of rest or peace. We are, however, thrust into a state of being where we must constantly face outside stimuli. Thus, one way the desire for destruction appears is through the destruction of stimuli and the quieting of the mind. I think, however, that Freud's conception of a true death drive is much different from what Spielrein talks about in her article. I would argue that what can truly be called a drive towards death is a desire to cease to be, to die. This is more than a desire towards

48 Peter Gay, Freud: A Life for Our Time, 395. 
de-structuring. It is a desire for complete dissolution. Freud argues for this desire towards complete dissolution when he talks about our internal drive to succumb to the death that is natural to us. This is different from the desire for the end of stimulation. The desire for non-stimulation is a desire to exist without stimulation. The drive toward death is an impulse for the termination of existence, for non-existence.

Freud talks about three main inclinations within humans that tend to interact with each other. These are the drive to repeat, the sex drive, and the pleasure principle. The drive to repeat impels us to repeat events from the past regardless of the pain or pleasure produced by the act. For Freud, this can range from repeating traumatic events from our past to repeating complex biological events from our ancestors, including death. Freud sees this as a manifestation of the death drive. The sex drive is simply the drive to reproduce. The pleasure principle is the drive humans have to increase pleasure and diminish pain. The way Freud believes this works is in relation to outer stimuli. When we are over-stimulated, we feel pain. When we stabilize the impact of these stimuli it creates pleasure. However, that pleasure is not a real pleasure. Freud only thinks of pleasure in a negative sense. It refers to the absence of pain. In Beyond the Pleasure Principle, Freud deliberates whether this drive acts in contradiction to the death drive or whether it acts in accordance with it. In a sense, he seeks to determine whether we regard death as an unpleasurable or pleasurable event.

It is perhaps the case that we should not place the death drive as acting against the pleasure principle. This drive is not called "beyond the pleasure principle" because it is the opposite of it. Rather, it is beyond the pleasure principle because it is indifferent to the pleasure/unpleasure dichotomy. It is not the case that the death drive compels us to do 
that which is unpleasurable. Instead, it urges us to repeat regardless of the pleasure or pain induced. Although she speaks of the death drive in a similar way, as the ego being driven by something other than pursuit of pleasure, Spielrein's article is not consistent in this view. In fact, she seems to say that there is a possibility of finding pleasure in the seeming pain that the death drive compels us toward. This is because what is painful for the ego-psyche turns out to be pleasurable for the species-psyche. It would seem, then, that she does not place the death drive outside of the realm of pleasure and pain (as is the case with Freud) or else she has a difficult time abandoning a framework where we operate solely to produce pleasure.

In addition to these three main drives, Freud talks about the three main parts of the structure of the psyche. These are the ego, the id, and the superego. Freud thinks that understanding the interplay of these three parts allows us to understand the operation of the death drive. ${ }^{49}$ It is interesting to contrast this with Spielrein's own method of talking about the death drive. While Freud uses the structure of the psyche to discuss how he believes a death drive comes into existence, Spielrein uses the concept of the death drive to discuss how the psyche is structured. What I mean by this is that Freud already has a system and structure for the psyche in place. He is adding the death drive to this system, trying to make it fit in with his previous theories. By contrast Spielrein is formulating her own concept of a psychic structure around the postulated existence of a death drive. This reversal is likely the case for two reasons. In the first place, Freud has a much more developed theory of the structure of the psyche. Therefore, he would speak of the drive in

\footnotetext{
${ }^{49}$ Sigmund, Freud, The Ego and the Id, (LaVergne, Tenn: Pacific Publishing Studio, 2012).
} 
terms of these concepts and not the other way around. Additionally, it is likely the case that Spielrein viewed the death drive to be a much more fundamental and overarching concept than Freud did. She saw it as pervasive throughout all aspects of life. Essentially, for Freud, structure precedes drives, whereas for Spielrein the reverse is the case.

It is important, therefore, to briefly discuss the three-fold structure of the ego before going any further on the nature of the death drive. The first fundamental part of the psyche that Freud discusses is the id. This is where he believes our instinctual impulses reside. In this part of the psyche we find instincts. The main instinct Freud believes that the id operates upon is the pleasure principle, but this is also where our other impulses reside, inherited by our ancestors before us. The second part of the psyche to consider is the ego. The ego directs the impulses of the id to the external world. It uses reason and judgment to determine how to make these impulses mesh with reality, which cannot always meet with our demands. Freud says, "In the ego, perception plays the part which, in the id, devolves upon instinct. The ego represents what we call reason and sanity, in contrast to the id, which contains the passions. ${ }^{" 50}$ Although the ego represents this reasoning part, a large part of it remains unconscious. The third part of Freud's structure is the superego. The superego represents the moralizing part of the psyche. It decides what one ought to do based on higher principles and not only based on the id's demands. The principles it acts on are the ones taught to us by elders or by our culture. The superego attempts to influence the decision-making processes of the ego. It can be said that the ego is the part of the psyche that attempts to take what it deems to be the best action based on the dictates of the superego and the impulses of the id. The best action

50 Freud, The Ego and the Id, 24. 
would be one that could satisfy both the superego and the id. Freud compares the interplay between the ego and the other parts of the psyche to a rider on a horse. He says, "Often a rider, if he is not to be parted from his horse, is obliged to guide it where it wants to go; so in the same way the ego constantly carries into action the wishes of the id as if they were its own." ${ }^{51}$ The ego develops the desires it has for itself through what is demanded by the id and the superego.

It is in light of these three drives and the three parts of the psyche that I will discuss Freud's notion of the death drive. In the rest of this chapter, I would like to go through two important works where Freud explains his take on the death drive. These are The Ego and the Id and Beyond the Pleasure Principle. Freud was likely prompted by Spielrein in writing Beyond the Pleasure Principle and pursues the concept in a similar vein as Spielrein. This is because he substantiates his ideas on the death drive through facts of biology. As well, his text is very dense and complicated as is Spielrein's essay. In his introduction to The Ego and the Id, he says that he has written this new essay to explain more deeply certain concepts brought up in Beyond the Pleasure Principle. This is because of the scientific/biological jargon to which Freud restricts himself in Beyond the Pleasure Principle. In The Ego and the Id, he explores these concepts in more of a psychoanalytic context. I will talk about these texts together to create a composite view of Freud's vision of the death drive.

Repression

${ }^{51}$ Ego and Id, 24. 
Freud starts off The Ego and the Id with talk of the idea of repression. Like Spielrein, he sees repression as an essential building block towards uncovering the secrets of the death drive. He claims, "We obtain our concept of the unconscious, therefore, from the theory of repression. The repressed serves us as a prototype of the unconscious." 52 It is helpful, therefore, to iterate what repression is in simple terms if we are to gather how the unconscio us (the death drive in particular) works. In the simplest terms, repression occurs when two conflicting desires are present at the same time. They are conflicting in that the realization of one desire would conflict with the realization of the other. When this happens, one desire is repressed, forced away from the conscious so that the other may triumph without any impediment.

We could map out Spielrein's argument in these simple terms. For Spielrein, our two conflicting desires are our impulse to avoid pain (and augment pleasure) and the impulse towards love and sex. She believes these two to be conflicting in a certain respect because she sees love and sex as painful processes. For this reason, in some people, impulses towards love and sex are repressed. For some people, however, the pleasurable experience of love and sex outweighs the painful components. In this case, that which is unpleasurable about sex becomes repressed. Spielrein's mission in writing her paper was to discover what this negativity was. From this, she developed her theory of the death drive. Freud, on the other hand, would set up Spielrein's problem in simpler terms. He would agree that the impulse to avoid pain and the impulse towards love and sex would be the two conflicting desires at play. He would have a simpler answer, though, as to what is painful about love and sex. He would say that we associate them with pain

52 Ibid, 4. 
because of how we are punished by our parents as children for engaging in them. There would be no need to delve into the further investigation serving as the basis for Spielrein's paper. Freud himself admits there are certain shortcomings to the theory. $\mathrm{He}$ says, "The details of the process by which repression turns a possibility of pleasure into a source of unpleasure are not yet clearly understood or cannot be clearly represented; but there is no doubt that all neurotic unpleasure is of that kind - pleasure that cannot be felt as such. ${ }^{, 53}$

Freud equally uses the idea of repression to set up his main inquiry into the death drive. His starting point is what he views as our compulsion towards repetition. Freud finds examples of the compulsion to repeat in many aspects of life. He sees it in the tendency of people to recreate traumatic experiences from their past. He sees it also in the way that we seek to repeat life-cycle patterns of our genetic ancestors. This compulsion leads us towards our own death, because we wish to return to the state of nothingness from which we came, to repeat that state of being. The two desires in Freud's argument are then the impulse to diminish painful stimuli and the impulse to repeat past events (often traumatic events that are painful). In Spielrein's case, the pleasure principle sometimes defeats the impulse towards love and sex. The impulse towards love and sex is repressed in certain individuals because they are not conducive to producing pleasure to the ego in that they result in its destruction. What is interesting in Freud's case is that the pleasure principle does not necessarily force the impulse to repeat away from consciousness. What is interesting to Freud is that it does not cause the repetition impulse

\footnotetext{
53 Sigmund Freud, Beyond the Pleasure Principle, (Mineola, New York: Dover Publications, Inc, 2015), 5.
} 
to become repressed. From this, Freud believes there to be another instinct with equal potency to the pleasure principle to be at play. He believes that beyond the pleasure principle, operating outside its bounds, we can find the death drive.

\section{The Organism and External Stimuli - Pleasure Principle and Reality Principle}

An important concept for Freud is the idea of the individual organism trying to achieve a state where it is minimally bothered by external stimuli. This is the constancy principle. Jean Laplanche says, "The principle of constancy is closely allied with the pleasure principle, in that unpleasure can be seen in an economic perspective as the subjective perception of an increase of tension, and pleasure as corresponding to a decrease in it." 54 This relates to the pleasure principle because Freud believes that we experience unpleasure when we are bombarded with stimulation. Pleasure occurs when we are able to minimize or else stabilize the stimuli that we encounter from the external world. Freud says, "The mental apparatus endeavours to keep the quantity of excitation present in it as low as possible or at least to keep it constant." 55 Essentially, he views pleasure in a negative sense. Pleasure is about easing a state of pain, or unpleasure. This state of pain is being stimulated - experiencing excitation that is not discharged. We can stabilize these excitations by acting towards easing the tension created by them. If we encounter somebody who arouses us, we can take action to ease that tension through intercourse with that individual, thus easing the excitation created by arousal. In this way, we create pleasure. Alternatively, in Freud's system, we can minimize stimuli by shutting ourselves

\footnotetext{
54 Jean Laplanche and Jean Pontalis, The Language of Psychoanalysis (New York: Norton, 1974), 341

55 Beyond the Pleasure Principle, 2.
} 
out from the external world entirely, but this is never perfectly realizable - we cannot completely shun the external world. We have to always interact with what is outside of us in some way because we need it to sustain our life. We would need to interact with the world at the bare minimum to get nourishment for survival. Freud calls this idealized state of zero stimulation, that can never be realistically achieved, "Nirvana."

The absence of all stimulation is then what Freud sees as the ideal state. This is the state where I think the death drive is most apparent in Freud's work. In this state, we are essentially dead to the world. We are unaffected by all that is around us. It could equally be said that the world is dead to us. However, no such thing is possible in the real world. The closest thing would be something like sleep, or death. On the one hand the death drive is the drive for the self to die (to be dead to the world). On the other hand, it is the drive to destroy all outer stimuli (for the world to be dead to the self). Freud believes that this state ultimately leads to a death of the organism itself. In this real world, however, to aim at such a state of being leads to death. We live life on our own terms; the interaction of chemicals within us eventually stagnates and abolishes itself. However, if we add outer stimuli to the mix (in the form of a reproductive partner), we can create new life. ${ }^{56}$ Thus, by interacting only with the self, we create a state of death. By interacting with outer stimuli, we create life.

Freud considers that the organism has two essential ways it comes to interaction with the external world. The first is to receive stimuli, the second to protect against them. He believes the second function to be a more essential one. This is because it is geared more towards ensuring the survival of the organism. He talks about the physical exterior

56 Ibid, 48. 
of organisms, with skin, and shells that protect them from external stimuli entering into them. The interior, however, does not have this same protection. These physical protective layers are paralleled by a psychical element. Freud claims that "Consciousness is the outer appearance of the mental apparatus; that is, we have allocated it as a function to the system that is situated nearest to the external world." ${ }^{57}$ Consciousness is the stimulus layer through which the individual organism interacts with the external world. Consciousness concerns itself with determining the appropriate action (sometimes disregarding the pleasure principle) to ensure protection and survival of the organism. This concern with interacting realistically with the external world - that is to say interacting with a world that does not meet up with the ideal conditions for realizing our desires such as situations where achieving our desires would cause harm to us - is what Freud calls the reality principle. It acts regardless of the dictates of the pleasure principle These two sentiments appear, at first, to be contradictory. Essentially, Freud describes the pleasure principle as a process aimed towards reducing the effects of external stimuli. He similarly describes the reality principle, which is said to be that which is "beyond the pleasure principle", as a process aimed towards protecting the organism from the effects of external stimuli. However, this does not mean that the two principles are the same thing. Although they act out the same processes, their ultimate goals are different. The pleasure principle acts in order to produce pleasure. The reality principle acts in order to ensure survival. Furthermore, there is another aspect in which they are not necessarily the same. In the example I have given above of the person who arouses us, the pleasure principle tells us to have sex with them to produce pleasure and

${ }^{57}$ Ego and Id, 14. 
ease the tension created by arousal. If having sex with the person would create a dangerous situation (perhaps this person already has a very jealous and violent partner), the reality principle would tell us not to engage in it.

Freud believes that the existence of this process beyond the pleasure principle to be fairly evident. He says, "It is incorrect to talk of the dominance of the pleasure principle over the course of mental processes. If such a dominance existed, the immense majority of our mental processes would have to be accompanied by pleasure or lead to pleasure, whereas universal experience completely contradicts any such conclusion."58 Not only is the pleasure principle not the only process at play, but Freud emphasizes that it is not the dominant principle either. This should not be a big surprise. When we speak biologically, we do not envision humanity as geared towards producing pleasure. Rather, we believe humanity to be more invested in ensuring its own survival.

Simply, when the pleasure principle is not conducive to reduction of pain, here the reality principle steps in. 59

Repetition

In Beyond the Pleasure Principle, Freud discusses a game played by a little boy (who happened to be his grandson). In this game, the boy throws a spool out of his crib saying "ooooo" which was interpreted as "fort" meaning "gone. While pulling the spool back in he says "da" meaning "there". 60 Freud interprets this as an action stemming from the boy's relation to his mother, whom he loves dearly. The boy throws away the objects

${ }^{58}$ Beyond the Pleasure Principle, 3.

${ }^{59}$ Ibid, 4.

${ }^{60}$ Peter Gay, 400. 
because he is re-enacting the mother leaving him, pre-empting the anxiety he feels when she leaves the house. ${ }^{61}$ Freud says,

The danger situation is the recognized, remembered and anticipated situation of helplessness. Anxiety is the original reaction to helplessness in the traumatic situation, which is later reproduced as a call for help in the danger situation. The ego which has experienced trauma passively, now actively reproduces an attenuated reproduction of it with the idea of taking into its own hands the directing of its course. ${ }^{62}$

In cases of repeating trauma, the ego protects itself against external stimuli by pre-emptively re-enacting the danger it anticipates. It takes the potential hurt that would be inflicted from the outside and inflicts it internally, thus assuming control over it. Thus, it is no longer unexpected and cannot take the ego by surprise - the ego has sufficiently prepared for the danger. The little boy throws the toy away from him before the mother can throw him away from her. Peter Gay says the child was "moving from passive acceptance of his mother's absence to the active re-enactment of her disappearance and return. Or perhaps he was revenging himself on his mother-throwing her away, as it were, as though he no longer needed her." 63

Freud conceives of the process of repetition as a way of dealing with unpleasant external stimuli. It is a way of taking into our own hands and directing the course of an event over which we previously had no control. Because we do not choose to live but life is thrust upon us, it is something over which we have no control. We seek to exercise control over it through repetition of our trauma. Freud says,

An instinct is an urge inherent in organic life to restore an earlier state of things which the living entity has been obliged to abandon under the pressure of external disturbing force, that is, it is a kind of organic elasticity or the expression of the

${ }^{61}$ Beyond the Pleasure Principle, 11.

${ }^{62}$ Freud, The Problem of Anxiety, 150.

63 Peter Gay, 400. 
inertia inherent in organic life. The elementary living entity would from its very beginning have had no wish to change; if conditions remained the same it would do no more than constantly repeat the same course of life seeking to reach an ancient goal. ${ }^{64}$

The law of inertia, or Newton's first law, says that a body at rest will stay at rest or a body in motion will stay in exactly that motion unless it is acted upon by an outside force. Freud believes inertia to be something that operates on a psychical level as much as it is a property of matter on the physical plane. We long to be mentally undisturbed by the outer world and remain in this state of peace, of not being moved. If we are at peace, without stimuli, we seek to remain at this state of peace. If we are in a state of movement (or minimal disturbance by outside forces), we will seek to remain moving (or receive outside stimuli) at this same pace. This is in line with the idea of the pleasure principle. Freud believes that we were in the state of rest or non-movement before we were given life and that this natural state of the organism is something like death. He sees life as a spark that is given to us from something outside of us - it is like all the other external stimuli that Freuds says we wish to stabilize or minimize. The death drive is that force underlying our thoughts and behaviours which impels us to repeat the act of death which is natural to us, in opposition to the act of life which is forced upon us from an external source. Our ancient goal is therefore to die and repeat the past in which we found ourselves in a death-like state. Our ancient goal is to remain at rest.

Freud also sees this urge to repeat on a smaller scale. It is not just about repeating large scale events such as life or death. Rather, what initially sparked Freud's interest in repetition was people's tendency to repeat traumatic events occurring in their past. This is expressed in a number of ways. One way in which we repeat these events is in our

${ }^{64}$ Beyond the Pleasure Principle, 30. 
dreams. Another way is by repeating the same events in our own future. We see often how someone who has been abused as a child goes on to be an abuser themselves. Another way Freud says that traumatic events are repeated is through child's play.

\section{Biology}

Freud's notion of the death drive also involves a recognition of fundamental biological reality, similar to Spielrein. In analyzing Freud's biological account, it is important to remember that he was operating with the knowledge of an old biology that does not meet today's standard. To set up his argument from biology, Freud says, "If we are to take it as a truth that knows no exception that everything dies for internal reasons - becomes inorganic once again - then we shall be compelled to say that the aim of all life is death." ${ }^{\circ 5}$ Freud takes it for granted that there was some initial force, a beginning, which caused the spark of life. This force was external to the organism. He says that the cause of this spark of life may well be the same as the cause of consciousness. The internal state of the organism, however, is non-being or inanimation. There is therefore a tension eternally present. We were brought into being from the non-being to which we are destined to return.

What then are we to make of self-preserving instincts if death is something which is so natural to us? What is the aim of a process as unnatural as preserving life? What is the aim of creating new life? Freud talks about this as it relates to the reproductive instincts. He says,

On our hypothesis the ego instincts arise from the coming to life of an inanimate matter and seek to restore the inanimate state; whereas as regards the sexual

${ }^{65}$ Beyond the Pleasure Principle, 32. 
instincts, though it is true that they reproduce primitive states of the organism, what they are clearly aiming at by every possible means is the coalescence of two germ-cells which are differentiated in a particular way. If this union is not effected, the germ-cell dies along with all the other elements of the multicellular organism. It is only on this condition that the sexual function can prolong the cell's life and lend it the appearance of immortality. But what is the important event in the development of living substance which is being repeated in sexual reproduction, or in its fore-runner, the conjugation of two Protista? ${ }^{66}$

Ultimately, Freud does not know what the important event being repeated could be. He considers the idea of Aristophanes' myth in the Symposium about how humans were once composed of both male and female parts but ultimately dismisses this. ${ }^{67}$ Thus, Freud is not successful in proving his claim that the life instincts also act towards repetition. However, some of what Freud says here has echoes of what is said in Spielrein's paper. Spielrein says that when we engage in the act of reproduction part of us dies in that we lose our sex cells (because they are altered in shape into an embryo). Freud, on the other hand, claims that the reproductive act can only be seen as resulting in death if it fails to produce offspring. What Freud cannot figure out though is why we would want to create more life if our ultimate goal is to end life. He does not understand why we would engage in the repetition compulsion for this part of the life cycle.

Freud also raises the problem of why we would have instincts to protect our own life if we ultimately want it to be destroyed. He answers that "the theoretical importance of the instincts of self-preservation, of self-assertion and of mastery greatly diminishes. They are component instincts whose function is to assure that the organism shall follow

\footnotetext{
${ }^{66} \mathrm{Ibid}, 37$.

${ }^{67}$ Caropreso, Fátima and Richard Theisen Simanke. "Life and Death in Freudian Metapsychology: A Reappraisal of the Second Instinctual dualism." International Journal of Psychoanalysis 89, no. 5 (2008): 977.
} 
its own path to death, to ward off any possible ways of returning to inorganic existence other than those which are immanent in the organism itself." ${ }^{\prime 68}$ The instinct towards selfpreservation serves our other instincts, the death instinct in particular. Freud holds that death is an internal natural state of an organism. The organism is fated to die; its systems are fated to fail of internal causes. The aim of the organism is not to succumb to death through external forces, then. That would go against its nature. Rather, it is oriented towards achieving death on its own terms. Therefore it protects the organism from death that is unnatural - seeking still to diminish the effects of outer stimuli - so that it can achieve death through natural causes - the deterioration of the organism itself from internal forces.

What then are we to make of the sexual instincts which perpetuate life? As stated above, we are to view them also as instincts that are subservient to others. These reproductive instincts serve our desire to diminish stimuli and to die. In a similar vein to Spielrein, Freud talks about the fact that certain species die in the act of copulation. He says,

The ejection of sexual substances in the sexual act, corresponds in a certain degree with the separation of soma and germ-plasm. This accounts for the likeness between dying and the condition that follows complete sexual satisfaction, and for the fact that death coincides with the act of copulation in some of the lower animals. These creatures die in the act of reproduction, because after Eros has been eliminated through the process of gratification, the deathinstinct has a free hand for accomplishing its purposes. ${ }^{69}$

Spielrein says that humans as a highly evolved species have moved away from actually dying in the sexual act to only a part of them dying (their sex cells). However, we derived

${ }^{68}$ Beyond the Pleasure Principle, 33.

${ }^{69}$ Ego and Id, 63. 
this from animal forms which do die during sex. Freud believes that a sort of death during sex is derived from lower species. Unlike Spielrein, Freud does not consider the death to occur from the reproductive factor of copulation. It is not due to the fact that our sex cells die that we achieve death through copulation. Rather, it is due to the discharge of excitation that death has been achieved. Freud compares actual death to how humans are after orgasm. He says,

We cannot yet decide with certainty in favour of any of these ways of putting it; but it is clear that the function thus described would be concerned with the most universal endeavour of all living substance - namely to return to the quiescence of the inorganic world. We have all experienced how the greatest pleasure attainable by us, that of the sexual act, is associated with a momentary extinction of a highly intensified excitation. The binding of an instinctual impulse would be a preliminary function designed to prepare the excitation for its final elimination in the pleasure of discharge. ${ }^{70}$

The moments leading up to sex are some of the most tense and exciting moments we experience in life. They are full of anticipation of the relief of our arousal. Thus, they are some of the most painful moments according to Freud's pleasure principle. This does not seem immediately evident. At first, it seems that part of the joy of sex is the excitation and arousal. We only say this, though, because our excitation is often relieved through sex. If we were incapable of relieving our arousal, we would not find excitation pleasurable at all. Thus, Freud's point holds that what is pleasurable about sex is discharge, thus abiding by his pleasure principle and ultimately, the death drive.

So, we could say that we repeat life instincts in order to achieve discharge. They would not in fact be acting against the death instincts but in service of them. There could also be an alternative explanation. We could say instead that the life instincts operate

\footnotetext{
${ }^{70}$ Beyond the Pleasure Principle, 55.
} 
against our death instincts in order to make death possible in the future. Rather than preserving the life of the specific organism, they preserve life itself, allowing for the death of ensuing organisms. Freud says, "One group of instincts rushes forward so as to reach the final aim of life as swiftly as possible, but when a particular stage has been reached the other jerks back to a fresh start to prolong the journey." ${ }^{.71}$ Essentially, he views both life and death instincts as conservative instincts. The reason why life instincts exist in spite of our drive to die is because these life instincts seek to preserve a state of being. Once we are given life, the conservative nature of our drives dictates that we must preserve this life. Freud says,

On the other hand, we supposed that Eros aims at complicating life by bringing about a more and more far-reaching coalescence of the particles into which living matter has been dispersed, thus, of course, aiming at the maintenance of life. Acting in this way, both the insitincts would be conservative in the strictest sense of the word, since both would be endeavouring to re-establish a state of things that was disturbed by the emergence of life. The appearance of life would thus be regarded as the cause of the continuance of life and also as the cause of striving towards death. Life itself would be a conflict and compromise between these two trends. The problem of the origin of life would remain a cosmological one; and the problem of the purpose and goal of life would be answered dualistically. ${ }^{72}$

We must recall Freud's earlier point about inertia. To restate, the law of inertia says that bodies at rest will stay at rest and bodies in motion will stay in constant motion unless they are acted upon by an external force. We must recall also that Freud views life as something thrust upon us from an external source. It is the force that gives us motion. We can view death as being the state of rest. Once we are thrust into motion, we will seek to maintain that momentum (because bodies in motion stay in constant motion). Thus, once

\footnotetext{
${ }^{71}$ Ibid, 35 .

${ }^{72}$ Ego and Id, 51.
} 
we are thrust into life, we will seek to maintain that life. However, fundamentally underlying this is the desire not to be moved further. We do not wish for external forces to move us. If we take this desire not to be moved further to its conclusion, it is a desire not to be moved at all, a death drive. However, because life is thrust upon us, we must maintain it. It is thus that Freud views both life and death instincts as ultimately serving inertia, or conservatism. Thus, the two are not contradictory. Maintaining both these processes is what Freud views as the very purpose of our having life.

Freud thus ties the repetition compulsion to the sexual instincts. The sexual instincts are tied also to reproduction. They are what make the process of life and death a never-ending one. When one organism dies, its offspring takes up the same life process all over again, leading to an eternal cycle. Because new life is brought into being, we must repeat the death stage of the life-cycle. The problem with this conception of life and death instincts is that we don't know the origin of sexual instincts. Thus, we don't know how far back we are repeating. ${ }^{73}$ This is potentially problematic in that Freud thinks that the death drive is something we have inherited from our distant biological ancestors. $\mathrm{He}$ believes it to be something that is shared across all living things because of his argument from inertia. All organic forms of matter are disturbed by the life given to them by external forces. Not all organic matter, however, reproduces sexually. Many reproduce asexually, and it is impossible to determine, then, if they truly can die in the same way humans do insofar as the offspring of asexual organisms are genetic clones. Furthermore, there are some forms of organic matter that do not need to die at all. These organisms are

${ }^{73}$ Ibid, 49. 
known as biologically immortal and do not die of internal causes, rather they can only be killed by outside predators or elements.

We could solve this problem simply by stating that Freud's statements do not apply to all organic matter. He deals in particular with humans so his statements are likely applicable only to organisms which are complex like humans. It is clearly the case, however, that he would not agree to this. One of Freud's claims is that our compulsion to repeat is found in the way we develop in utero. He says, "We see how the germ of a living animal is obliged in the course of its development to recapitulate (even if only in a transient and abbreviated fashion) the structures of all forms from which it is sprung, instead of proceeding quickly by the shortest path to its final shape." ${ }^{\prime 74}$ The way that an embryo develops involves stages that are similar in appearance to the shapes and forms of genetic ancestors in our evolutionary process. He questions why we must go through these stages and not just straight to our final form. He hypothesizes that this is because of our compulsion to repeat. This is not the best argument, but it shows that Freud believes the repetition compulsion to be at least a cross-species phenomenon, as he says this occurs in the germs of all living animals. It is not the best argument because science now shows us that this is not really the case in the development of an animal. It is certainly not the case with human development in utero.

\section{Aggression}

So far, we have mostly discussed the death drive in terms of the way it relates to the self (the desire of the self to die). However, Freud believes that the death drives also acts

${ }^{74}$ Ibid, 31. 
towards other people in the desire to kill. This relates to an earlier point I had made about the pleasure principle. According to the pleasure principle, we wish to reduce external stimuli. I previously said the ultimate goal of this is to make ourselves dead to the world, or else to make the world dead to us. I believe this relates to the inward and outward directions of the death drive. We can either want ourselves or others to die in order to make outer stimulation end. To his discredit, Freud does not really explain how this occurs. It is unclear exactly how the death drive is responsible for aggression. We are to take it for granted that our drive to reduce outer stimuli is a desire to destroy and thus act out at the stimuli with aggression.

Freud mostly talks about aggression in terms of how it is expressed in sexuality, referring to it as sexual sadism. He says, "We perceive that for the purposes of discharge, the instinct of destruction is habitually enlisted in the service of Eros." 75 Freud finds it interesting that aggression (an expression of the death drive - Thanatos) could be used for the purpose of the sex drive or life seeking impulses (Eros). At first glance, it seems that the two are incompatible. However, Freud concludes that the two work together when they act in service of our greater impulse, to reduce stimulation. In this case, the reduction of stimulation occurs through discharge. Sexual aggression allows us to be relieved of our feelings of arousal

The question then becomes how aggression allows us to relieve this arousal. Why do we resort to aggression in sex instead of engaging with the other on gentler terms? Freud poses and answers the question:

But how can the sadistic instinct, whose aim is to injure the object, be derived from Eros, the preserver of life? Is it not plausible to suppose that this sadism is in

75 Ibid, 52. 
fact a death instinct which, under the influence of the narcissistic libido, has been forced away from the ego and has consequently only emerged in relation to the object? It now enters the service of the sexual function. During the oral stage of organization of the libido, the act of obtaining erotic mastery over an object coincides with that object's destruction; later, the sadistic instinct separates off, and finally, at the stage of genital primacy, it takes on, for the purposes of reproduction, the function of over-powering the sexual object to the extent necessary for carrying out the sexual act. ${ }^{76}$

This goes back to repetition and mastery. Essentially, we seek to be masters over our own lives. We wish to determine how the course of our lives will go and not have outer circumstances dictate that for us. This relates back to us determining the course of our own death and to our desire to diminish outer stimuli. We try to do these things on our own terms. Therefore, we wish to engage in the sex act on our own terms, to be masters over that particular stimulus. The other person becomes an object towards fulfilling our own purpose, to diminish stimulation. Therefore, we seek to dominate them so that we will no longer be aroused, allowing us to achieve our desired discharge. Freud is not, however, describing all sexual relationships here. He is describing those where the impulse towards mastery is taken to the extreme of actual sexual sadism (which is not a common phenomenon among individuals).

This discussion of other people being seen as objects to the self is essential in setting up the next chapter of this thesis. The next chapter discusses Melanie Klein, who views object relation to be essential in how we conceive of the death drive. In Beyond the Pleasure Principle, Freud says, "Now object-love itself presents us with a second example of a similar polarity - that between love (or affection) and hate (or aggressiveness)." $" 77$. This occurs in a similar way to how the death drive involves both

\footnotetext{
${ }^{76}$ Beyond the Pleasure Principle, 47.

${ }^{77}$ Ibid, 47.
} 
death and life instincts. Klein's polarity, however, is different. She thinks that in loving relationships, we split the object into two - one being the good object, the other the bad. We engage with the good object through gratitude while we engage with the bad object through envy. The title of her main work that I will discuss is indeed Envyand Gratitude.

\section{Conclusions}

I believe Freud is operating on two definitions of pleasure. The first type of pleasure is the common usage of the word pleasure. It is something one would find enjoyable or pleasing. If we are to think of pleasure on these terms, then we can see why Freud was trying to come to terms with a principle beyond that of pleasure. It would seem that the death drive and the reality principle do act on a basis beyond this principle.

However, Freud explicitly does not define pleasure by these terms. He states over and over that the pleasure principle says that we derive pleasure by seeking to reduce stimulation (which is not the common theory of pleasure). Every other principle or instinct that he talks about actually seems to operate within these bounds. He discovers nothing beyond the pleasure principle. I will briefly explain my interpretation of the main instincts Freud discusses and how they relate to each other. This will aid in explaining why Freud finds very little beyond his conception of the pleasure principle. These main instincts are: life instincts, death instincts (the death drive), the reality principle, repetition compulsion, and the pleasure principle. I argue that all of these serve the interest of the pleasure principle (which Freud calls conservative). Life instincts are aimed towards maintaining the life that is thrust upon us from the outside. We have these life instincts inasmuch as the pleasure principle relates to inertia. The death instincts serve the pleasure principle in the same way except that we seek death because it is the state of rest we were 
in before being moved by external stimuli. The way life and death instincts ultimately exhibit themselves is through the repetition compulsion, thus this too serves the pleasure principle. Finally, the reality principle serves the life instinct and thus the pleasure principle by proxy. It serves the life instinct because the reality principle steps in when the pursuit of pleasure leads us to life-endangering situations.

While Freud creates a lot of confusion about his terms, we can now derive a clear sense of what he perceives the death drive to be. The death drive for Freud is the drive to recreate our earlier state of being. This earlier state of being is described as inorganic, thus, we can say that it is like death (insofar as it involves not having life). It can express itself in other ways (namely through aggression) when it is directed outward to others. In his essay, Freud states that "the pleasure principle seems actually to serve the death instincts," ${ }^{, 78}$ but it is really the other way around. The death instinct serves the pleasure principle because the drive to reduce stimulation precedes the drive to reduce stimulation through death. That is to say, the aim of the death drive is to put an end to stimulation. This is achieved through death. The pleasure principle, on the other hand, aims toward the reduction of stimulation or else maintenance of it at a constant rate. The death drive is thus one way to achieve the aims of the pleasure principle. Life instincts equally achieve the aims of the pleasure principle through maintaining life at a constant rate. Therefore, Freud has found little beyond the pleasure principle and really just another manifestation of it through his explanation of the death drive.

Like Spielrein, Freud makes many grand claims about philosophical problems. In his study of the death drive, he finds two purposes of life. The first purpose of life is to

${ }^{78} \mathrm{Ibid}, 55$. 
die. Freud says it is an internal condition of the organism that it is fated to die. The other meaning Freud finds is to live, and to create new life. The problem of the origin of life, how life came to be, however, is something that Freud cannot answer. He believes simply that it is something given to us from an outside source. He seems also to make a similar claim as Spielrein about the state preceding life. She says that it is destruction that leads to life, that is the cause of life. Freud, on the other hand, says that it is Nirvana that precedes life. Before we were living, we were in a state somewhat like death in that were completely inanimate. 


\section{CHAPTER 3: KLEIN}

\section{Envy and Gratitude}

In the third part of my thesis I will discuss Melanie Klein, another classical psychoanalyst with insights on the death drive. Her own ideas on the death drive pertain to object interaction. Whereas Spielrein's essay focuses more on the masochistic manifestation of the death drive in self-destruction, Klein's view considers also the sadistic manifestation through the destruction of the good objects that surround us. If we are to compare her ideas with Freud's notion of pleasure and unpleasure, we can say that for Klein, the capacity for pleasure and unpleasure has fundamentally to do with our interaction with objects. Our reception of the object as a good object leads to feelings of pleasure or gratitude whereas when the good object is taken away it gives us feelings of unpleasure or envy/jealousy. These feelings of envy lead to a violent reaction against the object. It is in this tendency to react violently against the good object where Klein places the origin of aggression and the death drive.

It is important to understand what Klein means when she makes use of the term “object". For Klein, "object” does not necessarily refer to things outside of us. In fact, when she talks about good objects and bad objects, she is talking about internal parts of us. It is Klein's belief that when we interact with objects in our early infant stage, we create phantasies about the object. Objects that please us are good objects and those that do us harm are bad. This does not accurately portray the real external object, however. Instead, we project our own feelings onto the objects based on how we feel them to have treated us. This projection, then, based on our feelings about the objects is an internal phantasy. It is a part of our own psyche. 
Klein says that our first interaction with the other which shapes how all future relationships will take place is our interaction with the mother's breast. Anxiety is first introduced in the child when they are separated from the pre-natal unity they experienced with their mother in utero. Interaction with the breast through breastfeeding allows the child to regain a sense of this unity and eases the anxiety of separation, the disintegration of their first state of being. Furthermore, the breast meets the child's most basic need of nourishment. Thus, the mother's breast is the first good object leading to pleasure.

Klein differentiates between jealousy and envy. She says that jealousy is the fear of losing that which belongs to you, whereas envy is the pain of seeing others have what you want. Jealousy is more admirable as it implies a genuine love for the good object, whereas envy is less admirable because it stems from within and not from love of the good object. The good object becomes spoiled by envy. Klein says, "The infant's feelings seem to be that when the breast deprives him, it becomes bad because it keeps the milk, love, and care associated with the good breast all to itself." 79 Thus the breast threatens death because without it the child will starve. The child senses the possibility of death in the good object. This is problematic also for the child's sense of self. Klein says, "A good object is established which loves and protects the self and is loved and protected by the self. This is the basis for trust in one's own goodness." ${ }^{\circ 0}$ Envy however spoils the good object. It is destructive towards the Other. In turn, this destruction of the other leads to destruction of self because "the feeling of having injured and destroyed the primal object impairs the individual's trust in the sincerity of his later relations and makes him doubt

\footnotetext{
${ }^{79}$ Melanie Klein, Envy and Gratitude (New York: Basic Books, 1957), 11. ${ }^{80}$ Ibid, 19.
} 
his capacity for love and goodness." ${ }^{81}$ Thus, the feeling of envy creates a sense of anxiety about losing the good object. The fear of losing the good object leads one to destroying the good object by coming to see it as a bad object. Klein says it is the death drive that impels us to destroy the object. Therefore, the feeling of envy is what spurs the processes carried out by the death drive.

Klein's conception of the death drive here is a complicated and non-intuitive explanation of aggression. The drive impels one to destroy that which threatens ones own sense of satisfaction and well-being. However, there is a sense also in which the anxiety produced by this destruction turns inwards and destroys the subject's sense of self worth and their possibility of living a good life inasmuch as the object is a part of the self. Thus, Klein's explanation of aggression doubles as an explanation of self-destruction

\section{Envy, Jealousy, Greed}

In her book on Klein, Hanna Segal sets up the essential argument of "Envy and Gratitude," and the backbone behind Klein's views on the death drive. She says,

For the first time she formulates her view that envy rises in earliest infancy and its fundamental primitive form is directed at the feeding breast. The love, care and food received from the mother stir in the infant two opposite reactions: one of gratification leading to love, a primitive form of gratitude, the other of hostility and envy, based on the realization that the source of food, love and comfort lies outside one's self. ${ }^{82}$

Envy is not a sophisticated emotion, it starts out very early in life and is in fact one of the most primal feelings. Both love and hatred exist in early infancy and are manifested through gratitude and envy, respectively. The development of these emotions depends

${ }^{81}$ Ibid, 20.

82 Hanna Segal, Klein, (London: Karnac Books, 1989), 139-40. 
entirely on a relationship with an object outside of the self. This relationship, however, is only understood through the phantasy created by the infant. Klein thus takes on the largely relational aspect of Spielrein's essay. It is in the hateful, envy reaction to the mother's breast that we find what Klein calls the death drive. The death drive is our drive to react destructively towards the object when feelings of envy arise.

Klein makes it a priority to clearly define the difference between envy and jealousy as such terms often are intermingled in everyday use. Segal explains that although these were concepts used regularly in psychoanalysis before, Klein was the first to draw the distinction from everyday use. ${ }^{83}$ Klein explains the differences between envy and jealousy through reference to a triangular situation. She says that jealousy occurs in a triangular situation whereas envy occurs in direct relation to the object. Its original manifestation is the Oedipal triangle. It is based on the idea that the father is a rival for the desired object. One believes that the rival has full possession of the desired object, and fears this loss of the object, thus reacting with anger towards the rival. Envy, on the other hand, occurs only in relation to the desired object. It is where one thinks that the object keeps its good qualities all to itself, by prohibiting access to its good qualities. In this scenario, the anger and destructive tendencies are directed towards the desired object. ${ }^{84}$

Klein thinks it is also important to discuss the notion of greed and how it relates to envy and jealousy. Klein's concept of greed is the same as the way we tend to speak of it informally. It is the idea of desiring too much of something desirable. However, Klein

${ }^{83}$ Segal, 138-39.

84 Segal, 141. 
adds another dimension to it. In addition to greed being an excessive desire for something (more than one needs) it is also the case that it is the desire for something to an extent larger than the object can provide. Segal says that for Klein,

Greed aims at possession of all the richness of the object, beyond the need of the self or the capacities or willingness of the object. The damage done in greed is incidental. In envy the direct aim is to spoil the attributes of the object. This spoiling also has a defensive aspect, since, if the enviable characteristics are destroyed, one no longer has the painful experience of the feeling of envy. ${ }^{85}$

The destructive aspect in greed, then, is in trying to completely use up all of the good resource, which, as Segal says, incidentally results in harm to the object. The aim of greed is not directly to cause harm to the object. The destructive aim of envy, on the other hand, is to harm the object. It is done as a defensive mechanism. Klein's idea of envy echoes Freud's notion of mastery. We seek to make the object inferior to us by spoiling its good qualities. In doing so, we render the object less desirable to ourselves. Thus, we are no longer pained by the feeling of longing for it - a feeling that cannot be perfectly satisfied in as much as the primal object (the mother/mother's breast) does not belong to us. Furthermore, like Freud says, although the way we feel about an object is projected onto that object, the feelings towards the exterior world come completely from the interior. As such, Klein says, "It could be said that the very envious person is insatiable, he can never be satisfied because his envy stems from within and therefore always finds an object to focus on." ${ }^{\prime 86}$ Envy as a primal emotion does not necessarily arise from an object, but will find an object to fixate on. An envious person will never be satisfied

\footnotetext{
85 Segal, 141.

${ }^{86}$ Klein, 182.
} 
because they will always project their interior feelings of want, need, and desire onto some new object.

\section{Gratitude}

Klein stresses the importance of developing a good relationship with the breast because it will set the course for all our future relationships. She says, "I arrived at the conclusion that envy is a most potent factor in undermining feelings of love and gratitude at their root, since it affects the earliest relation of all, that to the mother. ${ }^{87 "}$ Envious people, therefore, cannot develop meaningful relationships or interactions with others. They will constantly view the other as an object who does not provide the goods that they desire and so will spoil all the positive qualities that the other possesses and view them only in a negative light. However, we do not necessarily have to react enviously towards the primal object. The cure for envy is gratitude. Although Klein says that it is often undermined by envy, it is the appropriate reaction to the breast which must be fostered in early infancy so that people can develop good relationships later on in life.

Klein derives her ideas of the breast as being the first object that provides gratification from Freud's theories. She says,

Freud described the infant's bliss in being suckled as the prototype of sexual gratification. In my view these experiences constitute not only the basis of sexual gratification but of all later happiness, and make possible the feeling of unity with another person; such unity means being fully understood, which is essential for every happy love relation or friendship. ${ }^{88}$

${ }^{87}$ Klein, 176.
${ }^{88}$ Klein, 188. 
Klein's theory branches out much farther than the bounds of sexuality. The gratification the infant receives from the breast is not just the basis for sexual gratification but all other types of gratification as well. Klein perceives gratification as the source of gratitude. The essence of gratitude can be understood as thankfulness and appreciation of having been gratified - having our needs understood and met. In our ideal initial state of union with the mother, all of our needs are immediately met by the mother in the optimally hospitable environment that is the uterus. Once the infant is separated from the mother, the mother has to try to understand what the child needs from her and to furnish her child with those necessities. New mothers go through great pains to determine what their child is trying to communicate through its cries, and whether their child is being adequately cared for. During pregnancy, these needs are mostly fulfilled unthinkingly, through natural automatic processes of the body. The infant ultimately aspires to the initial unity with the mother where needs are automatically fulfilled, but still feels gratitude when its needs are understood and met in some measure outside the womb.

Gratitude is important in developing future relationships for two reasons. Klein says, "Gratitude is essential in building up the relation to the good object and underlies also the appreciation of goodness in others and in oneself." ${ }^{\prime 89}$ On the one hand, a good relationship with the good object, in which we feel our needs to be satisfactorily gratified, fosters trust in those outside of ourselves. We can depend on outer objects and outer people to aid us in our survival - we do not need to fear or hate them. In fact, we are given room to appreciate that we do not need to ensure our survival on our own and feel grateful for others. In addition to this, though, trust in others leads to a trust in oneself. In

${ }^{89}$ Klein, 187. 
having our needs gratified, we are given a sense of love. As such, we feel as though we ourselves are lovable or worth loving. Thus, we can trust in ourselves that we will be able to maintain relationships in the future that will gratify our needs.

However, as much as our needs are met and as much gratitude we feel, we must constantly be on guard against envy. Paradoxically, this same gratification, which leads to the gratitude that counters envy, can also spur envy in the first place. Segal claims that, Envy of the breast is stirred by gratification, because gratification is proof of the infinite richness of the breast's resources. But envy can also, paradoxically, be stirred by frustration and deprivation. Since the infant idealizes the breast in his phantasy, when he is deprived he assumes that the riches he attributes to the breast are enjoyed by the breast itself. ${ }^{90}$

The problem with being gratified by the breast is that it is not ongoing. The infant does not get to experience the same continual state of gratification it felt in its experience of the mother. Furthermore, the infant becomes aware of the goods that the breast has to offer. The infant becomes resentful when it realizes that those goods are being kept away from it at times. It becomes envious and thinks that the breast is keeping that goodness to itself. In reality, we know that this is not how things are. The mother cannot constantly be providing her breast to the infant. Furthermore, the breast does not wish to keep the goods it provides to itself. The breast creates milk merely so that it can provide for the infant all of its goods are directed towards the benefit of the child. However, Klein is speaking of the point of view of the infant. In its infantile state, the child is not aware of these things. In fact, the child is so distant from seeing things this way that it compartmentalizes the mother into objects and does not view her as the whole person that she is. Primarily, the infant views her as two objects which Klein calls the "good breast"

90 Segal, 140. 
and the "bad breast" which become the prototypes for "good objects" and "bad objects" in general.

\section{Good object}

It is from the feelings of envy and gratitude that a divide occurs between these two concepts which Klein calls the "good object" and the "bad object". These are not actual objects with which the infant interacts, but the different ways in which it perceives the mother's breast. The infant fantasizes that these two ways in which it perceives the mother's breast are in fact two different objects in themselves. When infants grow older, they realize that the mother is a full person, and no longer sees the mother merely as a good breast and a bad breast. In their early interactions, though, they have developed the way in which they deal with feelings of envy and gratitude. Thus, through Klein's theory, we do not operate with others as an object relation. However, the way in which our future relationships are formulated is based off of our initial good object/bad object relation (inasmuch as they are informed by feelings of envy and gratitude).

For Klein, this early relation to the breast informs our later relationships by making a tie between psychical and physical gratification. Segal explains,

Those feelings are not related to the experience of the physical feeding only. For the gratified infant, the breast becomes the source of mental as well as physical qualities; he idealizes the breast and experiences it as the fount of love, understanding, wisdom and creativity, since it is capable of converting his state of distress into one of contentment and happiness. ${ }^{91}$

91 Segal, 140. 
Klein's picture refers often to the physical needs that the breast (or good object) provides for the infant. She says that inasmuch as we view the breast as nourishment for our physical need, it becomes the source of life itself, in that it sustains our life by providing for our needs. ${ }^{92}$ The breast is therefore highly idealized by the infant in terms of what it provides physically. This is paralleled, however, with the idealization of the emotional needs that it provides. As stated earlier, the good object provides the infant with the reality and the phantasy of trust. It is the fount of understanding and wisdom because it can recreate the state that the infant experienced in utero where its needs were fully met. Klein says, "This mental and physical closeness to the gratifying breast in some measure restores, if things go well, the lost prenatal unity with the mother and the feeling of security that goes with it. ${ }^{\prime 93}$ From the point of view of the infant, the idealized breast understands the infants' needs and provides for it. The good object becomes the new ideal (outside of unity with the mother) of what it means to feel loved and understood.

What preserves the goodness of the good object is that the infant separates it from the bad aspects of the mother's breast. The bad aspects are given a separate identity which Klein calls the "bad object". She says, "During the first few months he predominately keeps the good object apart from the bad one and thus, in a fundamental way, preserves it. ${ }^{\Re 4}$ In this way, envy cannot destroy the good object because the good object is only received with a sense of gratitude. Envy instead transfers all of the bad qualities of the breast to the bad object.

Bad object

\footnotetext{
92 Klein, 178.

93 Klein, 178-79.

94 Klein, 191.
} 
If the infant cannot make this separation, then it will have no early concept of feeling gratified by a good object. The infant will have no proper sense of love, support, and stability. Klein says, "Envy attacks the good object and, by projection and fragmentation, makes it bad; therefore it produces a state of confusion between good and bad, which is at the root of many psychotic confusions." 95 When envy attacks the good object, the infant has no root, no prototype, for the ideal love that the infant attributes to it. The infant has no sense of stability or safety. The good object becomes mixed with its negative attributes. For this reason, the infant develops a sense of a bad object - one that exhibits all the negative qualities observed in the good object.

Constantly providing, being a good object, for the child is not what will allow a child to develop a good sense of gratitude and be able to form strong healthy relationships in the future. It would not be possible to avoid the formulation of a bad object. Klein says, "An element of frustration by the breast is bound to enter into the infant's earliest relation to it, because even a happy feeding situation cannot altogether replace the prenatal unity with the mother". ${ }^{96}$ Even a mother who is very attentive to her child cannot be constantly at the child's beck and call. In fact, even if a mother did immediately respond with the good object to her baby's cries, it would still not be enough. If the baby must cry for what it needs, it has been left wanting. It has not experienced perfect gratification by the breast.

\footnotetext{
95 Segal, 143.

${ }^{96}$ Klein 179
} 


\section{Destruction of self}

Klein talks about the damaging effects of envy and the destruction (through the process of the death drive) of the good object inasmuch as it creates a lack of perceived goodness in oneself. This is because the infant doubts their worthiness of love and their ability to produce their own survival. This destructive element takes on another element in relation to the self because a part of the infant is destroyed as the good object qua phantasy is a part of the infant. Klein says,

I also came to see that the early process of introjection and projection lead to establishing within the ego, side by side with extremely 'good' objects, extremely frightening and persecuting objects. These figures are conceived in light of the infant's own aggressive impulses and phantasies, i.e. he projects his own aggression on to the internal figures which form part of his early super-ego. To anxiety from these sources is added the guilt derived from the infant's aggressive impulses against his first loved object, both external and internalized. ${ }^{97}$

In addition, then, to this lack of trust in self is a feeling of guilt. The good object represents ideal love for the infant. To destroy this object is to destroy all that is worth loving in the entire world. In the one sense, it creates guilt because the infant has destroyed its own hopes and chances at receiving love as well as its hopes at survival. Additionally, the infant loves the good object in return for the care that it provides. Thus, the infant feels guilty about its destructive envy because it has destroyed the one thing it loves most in the world. In this way, we can say that envy is a death instinct in two senses. On the one hand, it seeks to destroy the good object. On the other hand, this destruction of the good object threatens one's own existence (because the good object helps one survive). The death instinct for Klein operates thus on both internal and external grounds.

97 Klein, 27-28. 
We have discussed so far how destruction of the good object hurts the self because it challenges the infant's sense of being worthy of love by the good object. On the other hand, it also challenges the infant's capacity to love. Klein says, "The feeling of having injured and destroyed the primal object impairs the individual's trust in the sincerity of his later relations and makes him doubt his capacity for love and goodness." 98 If we are so capable of injuring this first, most important object in our lives, how are we to trust in our ability to form lasting relationships with good objects in the future? Furthermore, are we deserving of their love if we are capable of hurting something that is good?

Destroying the good object is also self-destructive in that it creates even more fundamental anxieties. Destroying the good object on the most basic level creates an anxiety about survival. Klein says, "The fear of being annihilated includes the anxiety lest the internal good breast be destroyed, for this object is felt to be indispensable for the preservation of life." 99 The child depends entirely on the mother and the breast for nourishment. This nourishment sustains the life of the child. If the child is to lose the object, the child's very survival is on the line. Therefore, destruction of the object is a very self-destructive act.

The earlier mentioned sense of guilt, however, is not just destructive towards the self. The sense of guilt can just as easily be turned back towards the object. Klein says, "It appears that one of the consequences of excessive envy is an early onset of guilt. If premature guilt is experienced by an ego not yet capable of bearing it, guilt is felt as

\footnotetext{
98 Klein 189

99 Klein, 30.
} 
persecution and the object that rouses guilt is turned into a persecutor." ${ }^{\prime 100}$ Guilt is a painful thing to experience. Because guilt is felt due to our envious interactions with the good object, guilt becomes associated with that object. As such, if the guilt is too painful to deal with and accept as stemming from the self, we place the blame on the object we associate with the guilt. Thus, the guilt we felt for destroying the object makes us hate the object more for making us feel guilty, leading to further destruction since we deem it our persecutor.

\section{Destruction of Other}

Klein believes we can find the source of the tendency towards aggression in the way we enviously attack the breast and in the way we blame it for our subsequent suffering. For Klein, this is defined as the death instinct turned outwards. She says,

The young infant feels that frustration by the breast, which in fact implies danger to life, is the retaliation for his destructive impulses toward it and that the frustrating breast is persecuting him. In addition he projects his destructive impulses on to the breast, that is to say, deflects the death instinct outwards; and in these ways the attacked breast becomes the external representative of the death instinct. ${ }^{101}$

The infant does not just feel persecuted because it feels guilt, but also because of that sense of impending doom. The infant does not realize that it creates for itself this sense of impending doom by exhibiting those destructive tendencies towards the breast. Rather, it is the breast's fault for making the child envious in the first place. In this way, the infant is doubly destructive towards the breast, first by attacking it through envying, secondly by identifying the breast itself as the persecutor which causes the negative consequences

100 Ibid, 194.

101 Klein, 31. 
of the envious attack. In addition to this, the infant attaches another fantasy to the breast. The breast is no longer merely the ideal signifier of love, care, and life. The breast also becomes the signifier of death. The presence of the breast represents life, but its loss (the negative breast, or bad object) represents a sort of death inasmuch as the phantasy within the infant dies.

There is no way the good object which one lost through aggression can be regained. Klein says, "A full restoration of the object to its original state of intactness and integrity is incompatible with envy. Only a manic reparation can be attempted in which the object is partially repaired, but the self remains in a superior position."102 The envious infant will always see themselves as a victim of the object they destroyed. As long as they remain envious, they will always see the object as having wronged them for not providing all the goods it has to offer. In a later phase of development, they may try to integrate the object back into their lives as something good from which to derive pleasure, it will never be seen in the same way. It is no longer the ideal provider of love. It now becomes seen as something fallible - a mix of both good and bad qualities. It is capable of both helping and harming the self. This, however, is an essential part of development for Klein. It is the move from the paranoid schizoid phase to the depressive position. These are important terms in Klein's work. The paranoid schizoid phase refers to this early stage of splitting the object into good and bad. The depressive position occurs when we recognize that the good and the bad can belong to the same object. We do not split it into good and bad anymore - it becomes one whole object with good and bad qualities. ${ }^{103}$

\footnotetext{
102 Segal, 143.

103 "Melanie Klein Trust." Depressive Position. Accessed April 30, 2018. http:/www.melanie-klein-trust.org.uk/depressive-position.
} 
Klein thinks it is very important in child development to not spoil the child. The child should have to overcome a little bit of wanting or envy in its early stages. For Klein, this wanting creates conflict in the child's life. In turn, conflict is essential for developing creativeness. ${ }^{104}$ The child needs to learn to become self-dependent, or independent, through creativeness. The good object cannot be entirely relied on for this throughout one's entire life. A person has to learn how to fend for oneself. They need to face certain problems in life and come up with ways to resolve them without someone else always providing for them.

\section{Real World Example}

I think a good example of how the potential negative effects of this primal relationship become re-enacted later in life is through the concept of the "friend zone". The friend zone was popularized by the 90's sitcom Friends but has now found a place in our common language. The friend zone occurs when one person wishes to be in a romantic relationship with someone but the other person wants to keep the relationship at the platonic friendship level. The friend zone is mostly perceived to be a negative thing because the person who wishes to pursue a romantic relationship is disappointed by the rejection he or she faces at the hands of his or her friend. He or she wants more from the friendship and that desire is not being met.

The desire to enter into a romantic relationship can in some respects be viewed as greedy. The time spent with the other person as the good object in a friendship, like the time the child spends with mother's breast, is not enough - like the greedy baby they

${ }^{104}$ Klein, 186. 
want more. Furthermore, as in Klein's definition of greed, the desire for the object goes beyond what the object is willing to provide. The object is not denying itself because it wishes to keep its goodness to itself. Rather, the object is not interested or willing to give more of itself to the one who desires a romantic relationship.

What is even more important, however, is how a person responds to this denial of the good object. On the one hand, he or she might want to stop being friends with the person who rejected him or her. He or she might start to view the object in a negative light for not returning the feeling. Often in the real world, people react by believing that the good object rejected them because the good object is really not a good person and only is attracted to bad people. This is to protect the desirer from feeling unlovable. It is not their fault that their friend doesn't want them back. It is the fault of their friend for having bad taste in romantic partners. To see the friend in this negative light would be to destroy the good object - to react with envy and aggression. The desirer destroys the good object that he or she initially had as a friend and turns the good object into a bad one. It is difficult to regain this friendship as the desirer now places his or herself on a morally superior ground. It could additionally be seen as an example of Freudian mastery. After having been rejected on a romantic level, the desirer now rejects the good object in terms of friendship before the object can reject them

Another possible reaction that the desirer might experience upon being rejected is to feel bad about themselves because they think they are not good enough for the object. The desirer might wonder what they did wrong and why the good object does not desire them in return. In reality, the object does recognize the good in the desirer - after all, the object wants to be friends with them - however they do not desire the desirer in the same 
way. Upon facing this rejection, the desirer might become hopeless and give up on the possibility of any future romantic partner because they do not believe in their own goodness or desirability.

On the other hand, a person who is resilient to this rejection by the good object might respond with gratitude. They might be grateful that they get to spend time with the good object at all. The desirer can appreciate the love and attention they get from their friend as things are and recognize the greed in asking for more from their friend than they are willing to provide. Furthermore, if the desirer has built up a good trust in self, they will know that it is not their fault that they have been rejected. They can trust that they still have good qualities and are fundamentally lovable (after all, they are loved as a friend). They also will not place the blame on their friend. They will love and trust their friend enough to respect their autonomy and appreciate the friendship they provide. The fact that the desirer's desire is not fulfilled would be perceived as merely an unfortunate circumstance, not something that requires someone to blame. The grateful desirer is developed enough to trust in themselves and their good object. The friendzone is simply the negative term used by the envious to describe what the grateful call friendship.

\section{Klein's Conclusion}

Klein believes that the way that the death drive exhibits itself is through the tendency to destroy the good object for the sake of envy. These destructive tendencies exist both in relation to self and in relation to others. Envy makes us believe that the good object is withholding itself from us. This would mean that it is not such a good object after all. If it did love us in an ideal sense, it would withhold nothing from us. In this fashion we destroy the goodness of the good object. By destroying the good object, 
however, we destroy ourselves. Because the breast is our most constant source of nourishment, by destroying the object we threaten our chances of survival. Furthermore, we destroy our faith and trust in our ability to create further relationships in life. Ultimately, this anxiety turns back towards the object. We act aggressively towards it because it comes to represent the death instinct. Its loss represents our own death. Thus, though we perceive the good object as the sustainer of life, we also see it as the ultimate threat when we react enviously to it. So, our life instincts lead us into further attacks of this object that threatens our survival.

\section{Ties to Freud and Spielrein}

Like Klein, Freud thinks that the symptoms involved in anxiety are derived from the birthing process. He says, "Anxiety in the human being takes the birth process as its prototype. Anxiety arose as a response to a situation of danger; it will be regularly reproduced thenceforward when such a situation occurs." 105 The sort of symptoms that occur in the birthing process are repeated in anxiety-inducing situations. For example, both situations involve an increase in respiration and an increase in heart rate. He also concludes that insofar as the mother meets the gratification of our most basic needs as an infant, she represents the first loved person; she is someone we long for.

When she cannot meet our needs, it is perceived as a danger because we are unable to provide for ourselves. We react with anxiety to this situation. "The situation which the infant appraises as 'danger' and against which it desires reassurance, is therefore one of not being gratified, of an increase of tension arising from non-gratification of its needs -

${ }^{105}$ Freud, The Problem of Anxiety, 94. 
a situation against which it is powerless." 106 This initial situation of the infant is indeed one in which they are powerless. It is not within their power to make the mother stay, to make her love them more. However, later in life, we are not so powerless in our relationship with others. Freud thinks the sort of danger which is the loss of the beloved later in life has direct connections to our internal states rather than being an entirely external danger. He compares the loss of the beloved with the idea of a wolf coming to attack. The wolf coming to attack is something entirely out of our hands. It has nothing to do with how we are as a person or how we have behaved towards it. It attacks us because it is a wolf and that is what it does. When someone we love leaves us though, it is not just because that is what they do. It is more likely the case that they have withdrawn their love either because they do not like who we are as a person or because we have behaved in such a way so as to hurt them. ${ }^{107}$ It is also our fault in another way. It is our fault for having developed feelings for the beloved object in the first place. Loving the mother was out of our hands - we needed her for survival and protection. When we have come to an age where we can protect ourselves, however, the loving is entirely in our hands. We can stop it from growing. We could have avoided feeling pain at the loss of the loved object. This supports the idea of the loss of the loved object as being a source for negative thoughts about the self insofar as the loved object has left due to our negative characteristics or that the pain we feel at their loss is our own fault.

A major difference between Klein and Freud is the relationship between the death drive and anxiety. Klein sees the fear of death not only as a source of anxiety, but as the

${ }^{106}$ Freud, The Problem of Anxiety, 100.

${ }^{107}$ Ibid, 114. 
primary source of anxiety, while Freud does not believe this. For Freud, the fear of death is just a fear of danger. We can never experience anything that could resemble death without actually experiencing death. We could therefore have no content to such a fear. Rather, what we fear when we think we fear death is the loss of the object. ${ }^{108}$ Klein believes that if there is a drive that seeks out death, there must be a part of us that can fear it. If the drive can have content, so can the fear - there must be a response to the drive that runs counter to human intuition. ${ }^{109}$ Furthermore, Klein thinks we can really have a concept of death because when we destroy an object, there is really a part of us that dies. This part that dies is the phantasy inside us. Klein believes that this type of death is just like what actual death would be like, but on a mental level. 110

Looking through Spielrein's lens, the loss of the mother would represent the loss of death of the ego as much as it does the loss of life. It was in the initial unity with the mother in utero that the organism "knew no I" - it existed without its ego, without individuation or consciousness of its separateness as an entity if we take Spielrein's account of the ego blending with the loved one to be true. The loss of the mother is the loss of the possibility of returning to this state in utero where the ego is, effectively, dead. In a similar sense, Freud might consider the unity with the mother to be close to a deathlike state. We are not bothered by outer stimuli and our needs are fully met. We would feel little sense of unpleasure because our needs would be met almost as soon as they arise. While I think the argument could be made that this would be similar to what Freud

${ }^{108}$ Rachel Blass, "On 'the Fear of Death' as the Primary Anxiety: How and Why Klein Differs from Freud." The International Journal of Psychoanalysis 95, no. 4 (2014):617. ${ }^{109}$ Ibid, 615.

${ }^{110}$ Ibid, 618. 
sees as a death-like state, the argument can only go so far. It is not a perfect psychical

death. Furthermore, we cannot know exactly how the infant feels or experiences things in utero. 


\section{CONCLUDING REMARKS}

In this section, I will attempt to summarize what each psychoanalyst has to say about the death drive. While their papers talk at length about where they believe the death drive to be located, how it operates and where it manifests itself, I will attempt to give a one sentence explanation of simply what a death drive means to them according to my interpretation. This way, we can arrive at a narrower and more simple definition of the death drive as understood by each psychoanalyst.

\section{Spielrein:}

The death drive is the drive to sacrifice, or destroy, the ego to join the collective.

\section{Freud:}

The death drive is the drive to die and to destroy outer stimuli in order to reduce stimulation and achieve nirvana.

\section{Klein:}

The death drive is the drive to destroy the good object (and consequently the self) when the good object strikes in us the fear of losing it.

When laid out in these simple terms, each psychoanalyst's conception of the death drive seems to be unique. It is difficult to see how they can be referring to the same thing. It is likely the case that they all are referring to different processes. However, they all seek to explain one common problem which is why humans are driven to destroy themselves. It is possible then that each psychoanalyst is describing a different manifestation of this drive to destroy. 


\section{Similarities and Differences}

As has been iterated throughout this thesis, there are many differences between each psychoanalyst's views on the death drive. There are also certain aspects that are shared between them. In evaluating these similarities and differences, it has been my hope to find something we can say that is held in common about the death drive. I will briefly examine what I think to be the greatest similarity and the greatest difference between the three.

To start, Spielrein and Freud emphasize the biological basis of their theories. Freud conceives of the death drive as primarily a biological drive. He believes that as organisms we are designed in such a way as to be thrust into a world of stimulation but with the desire to remain at peace. We have mental and physical apparatuses that protect us from these stimuli and attempt to diminish them. Spielrein also thinks the death drive has a biological basis, but in a different way. She believes that our mental life mirrors the fact that reproduction results in the death of sex cells. In the same way this biological process gives new life through a sort of death, so too do we create new relationships through the death of our ego. Klein's view is also shaped by biology. The primal anxiety for her is the fact that a child must be separated from its mother once it is born and no longer in her womb. This loss of the mother creates a desire to reunite with her through the breast. When the breast does not satisfy this desire to reunite, the death drive is provoked to destroy this good object.

An important dividing force between these three is the idea of interpersonal relationships. Spielrein and Klein think the death drive manifests through our 
relationships with others. Freud, however, thinks of it as a more individualistic phenomenon. For Spielrein, the death drive seeks to merge one's individual ego with the collective. This process depends entirely on people having the ability to form relationship with others. On the grand scale of Spielrein's picture, it means forming a relationship with the entire species. On a smaller scale, the ego can merge with others through relationships with loved ones. For Klein, the death drive requires one to be in a relationship with an outer object in order for it to manifest This is only partially true, however. While the death drive does need one to form relationships with outer objects in order for it to enact its destructive forces, it is not the case that it destroys those outer objects. Instead, it destroys one's inner phantasy of those objects. For Freud, the death drive is only concerned with outer objects insofar as they are bothersome stimuli. The death drive does not manifest itself in relationships with outer objects and instead prefers to avoid relationships entirely because relationships hinder the possibility of achieving complete peace of mind. Bothersome outer stimuli do not allow one to achieve a Nirvana state.

\section{What we can say about the death drive}

First of all, it is important to remember that none of these psychoanalysts believes that the death drive is a wish to die. This is true on two levels. For one, the death drive is not a wish or a desire, hence the use of the term "drive". The death drive is more of a force that guides us unconsciously to certain ends. Spielrein and Freud both use the death drive to explain sadism and masochism. We might understand sadism and masochism as desires or wishes. However, they do not say that sadism or masochism are the death drive, rather 
Freud and Spielrein claim they can be understood through the death drive. Thus, the death drive is not a wish or desire although it can be used to explain certain wishes or desires. Furthermore, in a strict sense, the death drive has very little to do with death. Its aims are not death. For Spielrein, the aim is to destroy the ego in order to merge with another. For Freud, the aim of the death drive is to reduce stimulation. For Klein, the aim is to destroy the object that harms us. In Freud's case, this sometimes is achieved through an actual biological death, but for each psychoanalyst, the death drive does not really need to achieve its aims through biological death.

Instead of death, what we are really talking about with regard to the death drive is destruction and self-destruction. Freud is the only of the three who really refers to the death drive as being a drive to an actual physical death. This is what I believe his second sense of the death drive to be. It is the idea that each organism is destined to die of internal causes. However, this sort of death drive is merely a drive to eventual, not immediate death. Furthermore, death is still not the aim in this process. The process is still to reduce stimulation and remain in a state of constancy or inertia by returning to a state of mental rest. Furthermore, the way Spielrein and Klein talk about death is not something like a biological death. Rather, Spielrein speaks of a death of the ego and Klein of a death of internal phantasies. Thus, when these psychoanalysts speak of a drive towards death, it is not necessarily a drive for one's organic life to end.

Another thing that should not be said about the death drive is that it is a force that opposes life instincts. The death drive and life instincts are often referred to as "Thanatos" and "Eros". Freud sets up these as two forces working against each other. However, he doesn't successfully show this. In the end, he believes that life instincts and 
death instincts both serve the repetition compulsion. Furthermore, it is the case with Spielrien that both the death drive and life instincts orient themselves to the same goal as they both are driven toward the reproductive act (albeit for different reasons). The death drive seeks the reproductive act so that it can destroy the sex cells and the ego. Life instincts seek the reproductive act in order to create new life.

A final thing we can say about the death drive is that it might be the source of aggression. Each psychoanalyst believes the death drive to be the source of aggression although they do not provide perfectly satisfactory accounts of why this is the case. Freud and Spielrein in particular do not go into great detail on this. Freud sees it as an outward expression of the drive to reduce outer stimuli but does not clearly explain how this process occurs. Spielrein focuses more on the self-destructive tendencies of the death drive. For her, the aggressive tendencies come out when one comes to see themselves as subject rather than object of the destruction that occurs when two egos merge. That is to say, one sees themselves as the author of the destruction of another being. Klein also falls short to some degree although she does provide an account. Her theory revolves around aggressive or destructive action directed towards the good object, but ultimately the good object is a part of our own internal life so the death drive is really self-destructive.

It would seem, then, that despite the best efforts of this thesis, there remains very little that can be said to be held in common by each psychoanalyst about how the death drive works and manifests itself. The death drive is still an elusive and mysterious topic. I do believe that I have found some common elements that might lead us to believe that they are all talking about a similar phenomenon, although the details of this phenomenon are still unclear. What I believe to be held in common is that the death drive is a drive 
derived from biological phenomena and that it is the force that leads us to destruction and self-destruction. Additionally, it is believed to be the source of aggression, albeit in very different ways and under different pressures, and though much remains to be said on how aggression springs from it. 


\section{References}

Primary Sources

1. Freud, Sigmund. Beyond the Pleasure Principle. Mineola, New York: Dover Publications, Inc, 2015.

2. Freud, Sigmund. The Ego and the Id. LaVergne, Tenn: Pacific Publishing Studio, 2011.

3. Klein, Melanie. Envy and gratitude and other works 1946-1963. London: Vintage, 1997.

4. Spielrein, Sabina, "Destruction as the Cause of Coming into Being." Journal of Analytical Psychology 39, no. 2 (1994): 155-186.

Secondary Sources

1. Blass, Rachel B. "On 'the Fear of Death' as the Primary Anxiety: How and Why Klein Differs from Freud." The International Journal of Psychoanalysis 95, no. 4 (2014): 613-627.

2. Caropreso, Fátima. "The Death Drive According to Sabina Spielrein." Psicologia. USP 27, no. 3 (2016): 414

3. Caropreso, Fátima. "The Death Instinct and the Mental Dimension Beyond the Pleasure Principle in the Works of Spielrein and Freud." The International Journal of Psychoanalysis98, no. 6 (2017): 1741-1762.

4. Caropreso, Fátima and Richard Theisen Simanke. "Life and Death in Freudian Metapsychology: A Reappraisal of the Second Instinctual dualisml." International Journal of Psychoanalys is 89, no. 5 (2008): 977.

5. Freud, Sigmund. Inhibitions, Symptoms and Anxiety. New York: Norton, 1977.

6. Gay, Peter. Freud: A Life for Our Time. New York: Norton, 1988.

7. Kerr, John. A Most Dangerous Method: The Story of Jung, Freud, and Sabina Spielrein. New York: Vintage Books, 1994.

8. Laplanche, Jean, and Pontalis. The Language of Psychoanalysis. New York: Norton, 1974.

9. Segal, Hanna. Klein. London: Karnac Books, 1989. 